\title{
Paweł Sasanka
}

Biuro Badań Historycznych Instytutu Pamięci Narodowej, Warszawa

\section{Historia walki na dwa fronty. Władza - prasa - dziennikarze 1953-1955/1956}

Zarys treści: Oparte o obszerne kwerendy archiwalne, prasowe i literaturę przedmiotu studium polityki prasowej partii komunistycznej i sytuacji w środowisku dziennikarskim w latach 19531955/1956, uwzględniające odmienną perspektywę centrum i peryferii, na tle przemian politycznych i kulturalnych. W pierwszej fazie destalinizacji polityka prasowa PZPR była rezultatem bardziej pragmatycznego kursu wyznaczonego przez ZSRR w krajach bloku po 1953 r. Gdy „odwilż” w Polsce nabrała własnej dynamiki, rozdźwięk w elicie PZPR i niespójna polityka sprzyjała poszerzaniu marginesu swobody prasy, zwłaszcza w stolicy. U progu 1956 r. część środowiska dziennikarzy, głównie młodych, buntowała się przeciwko modelowi prasy dyspozycyjnej, ograniczonej do roli narzędzia partyjnej propagandy.

Słowa kluczowe: prasa, dziennikarze, propaganda, polityka prasowa, „odwilż”, Polska 19531955/1956, Październik 1956, kryzys, komunizm

Keywords: press, journalists, propaganda, press policy, "The Thaw" in Poland, Poland 19531955/56, October 1956, crisis, communism

Głośny esej Witolda Jedlickiego Chamy i Żydy, opublikowany w 1962 r. na łamach paryskiej „Kultury”, otworzył dyskusję na temat charakteru i kulis polskiego Października. Jej istotnym wątkiem było pytanie o to, jakie znaczenie w budzeniu aktywności społeczeństwa miała prasa. Artykuł wzbudził sensację w kraju i na emigracji, ponieważ dobrze poinformowany autor po raz pierwszy, choć głównie na podstawie zasłyszanych informacji, opisał to, co wcześniej było tematem kuluarowych rozmów: podziały i walki frakcyjne wewnątrz, oficjalnie uchodzącej za monolit, Polskiej Zjednoczonej Partii Robotniczej ${ }^{1}$.

W swojej analizie Jedlicki marginalizował znaczenie presji wywieranej na władzę przez społeczeństwo i sprowadził Październik 1956 r. do walki dwóch skłóconych koterii partyjnych. Według niego jedna z nich - skupiona wokół Romana Zambrowskiego grupa „puławska” - posłużyła się prasą jako orężem,

${ }^{1}$ J. Giedroyc, Autobiografia na cztery ręce, oprac. K. Pomian, Warszawa 1994, s. 217. 
dzięki któremu pozyskała i wykorzystała do swoich celów nastroje społeczne. Jej sukcesem było wykreowanie mitu liberalizmu „puławian” - dekonstruowanego przez Jedlickiego - przeciwstawianego dogmatyzmowi grupy „natolińskiej”. „Rzeczą powszechnie uznaną jest rola prasy i intelektualistów w rozbudzeniu opinii publicznej i wywarciu presji na kierownictwo partyjne - pisał autor. - Powstaje jednak pytanie, w jaki sposób prasa, w której nic nie może być wydrukowane bez aprobaty cenzury, może wywierać presję na cenzorów lub ich szefów? A więc jedno z dwojga: albo prasa spełniała wówczas dyrektywy kierownictwa partyjnego, albo kierownictwo partyjne dobrowolnie $\mathrm{z}$ jakichś powodów godziło się na to, żeby prasa pisała to, co uważa za stosowne. W obu wypadkach nie ma mowy o żadnej presji”"

Dotychczasowe, zaawansowane już badania nad prasą w okresie 1955-1957 wskazują, że, niezależnie od ukazanej przez Jedlickiego rozgrywki politycznej, rzeczywistość była bardziej skomplikowana: w miarę rozluźniania gorsetu prasa i środowisko dziennikarskie rozbudzały aktywność społeczeństwa, którego presja przyczyniła się do doprowadzenia do politycznego przesilenia w październiku 1956 r. $^{3}$ Pytanie o mechanizm rozluźnienia owego gorsetu to pytanie o to, jak sytuacja polityczna w latach 1954-1956 wpłynęła na politykę prasową. Jak zmieniała się ta polityka, jak ją oceniano, jak postrzegano prasę w różnych, centralnych i lokalnych, segmentach aparatu władzy? Przywołany na wstępie esej Jedlickiego będzie tu istotnym punktem odniesienia, a jego pytanie będzie powracało wielokrotnie. Niniejszy tekst siłą rzeczy weryfikuje tezę postawioną przez Jedlickiego i można go rozumieć jako odpowiedź, a raczej wiele odpowiedzi na postawione przez niego pytanie.

Celem jest pogłębiona analiza polityki PZPR wobec prasy w latach 19531955/19564. Opiera się ona na założeniu, że w okresach destabilizacji dopiero

\footnotetext{
${ }^{2}$ W. Jedlicki, Chamy i Żydy, „Kultura” (Paryż) 1962, nr 12, s. 6-7; Październik 1956 [dyskusja nad arty kułem Witolda Jedlickiego Chamy i Żydy], Instytut Badania Zagadnień Krajowych, Londyn 1963 por. P. Ceranka, Historia pewnego artykułu, „Pamięć i Sprawiedliwość” 2006, nr 2(10), s. 93-114.

${ }^{3}$ Por. W. Władyka, Na czołówce. Prasa w październiku 1956 roku, Warszawa 1989; Z. Rykowski, W. Władyka, Polska próba - Październik '56, Kraków 1989; A. Kozieł, Studium o polityce prasowej PZPR w latach 1948-1957, Warszawa 1991; idem, Między rewizjonizmem a dogmatyzmem. Prasa polska w 1957 roku, w: Materialy pomocnicze do historii dziennikarstwa Polski Ludowej, red. A. Słomkowska, Warszawa 1988; idem, Polityka prasowa w 1956 roku, w: Październik 1956 roku. Poczatek erozji systemu, red. M. Jabłonowski, S. Stępka, Pułtusk 2007; W. Władyka, Lata 1956-1960, w: Czasopisma społeczno-kulturalne w okresie PRL, red. U. Jakubowska, Warszawa 2011; M. Przeperski, Władze i dziennikarze. Stowarzyszenie Dziennikarzy Polskich w 1956 roku, „Pamięć i Sprawiedliwość” 2014, nr 2(24), s. 95-134; idem, Odwrót od Października. Pacyfikacja prasy i dziennikarzy w latach 1956-1958, „Pamięć i Sprawiedliwość” 2016, nr 2(28), s. 311-352; idem, Komisja Prasowa KC PZPR 1956-1957, „Polska 1944/45-1989. Studia i Materiały” 14, 2016; T. Mielczarek, Od „Nowej Kultury” do „Polityki”. Tygodniki społeczno-kulturalne i społeczno-polityczne PRL, Kielce 2003.

${ }^{4}$ Zob. P. Sasanka, Władza - prasa - dziennikarze między XX zjazdem KPZR a Październikiem 1956 r., w: Nie tylko „Po Prostu”. Prasa w PRL dobie „odwilzy” 1955-1958 [w druku].
} 
zejście na niższy poziom struktur władzy i szersze spojrzenie pozwalają zrekonstruować proces zachodzący wewnątrz pozornie monolitycznego systemu; procesu, którego konsekwencją było rosnące znaczenie prasy i dziennikarzy w tym okresie. Takie spojrzenie opiera się na analizie aktywności najważniejszych centralnych gremiów partyjnych (plenarne posiedzenia Komitetu Centralnego, Biura Politycznego, Sekretariatu KC), struktur KC odpowiedzialnych za kierowanie i nadzorowanie prasy, wytworzonych przez nie instrukcji, listów, ocen, a także wypowiedzi I sekretarza KC, członków kierownictwa partyjnego i działaczy nadzorujących „front propagandowy” na różnych forach, w tym m.in. w czasie spotkań i narad z redaktorami naczelnymi i dziennikarzami. Znaczenie mają zmiany personalne w instytucjach i redakcjach kluczowych dla polityki prasowej. Analiza uwzględnia odmienną perspektywę centrum i peryferii, istotną dla rekonstrukcji wydarzeń w październiku 1956 r. i następnych miesiącach w ośrodkach wojewódzkich. W tym ujęciu publicystyka polityczna, ważna dla tożsamości ideowej lewicy październikowej, mająca już zresztą swoją literaturę̧, będzie istotna przede wszystkim ze względu na echo, jakim odbijała się wewnątrz aparatu władzy.

Dla zrozumienia meandrów polityki prasowej i postaw dziennikarzy w tym okresie - jak zawsze - potrzebne jest poznanie szerszego kontekstu, w tym przypadku stopniowego kruszenia stalinowskich okowów krępujących politykę, życie kulturalne i społeczne. Nie sposób traktować polityki prasowej w oderwaniu od otoczenia politycznego i społecznego: postępów odwilży. Do Polski docierały informacje o ostrożnej liberalizacji rozpoczętej w ZSRR po upadku Ławrientija Berii, o zwalnianiu więźniów z łagrów, o zmieniającym się klimacie prowadzonych tam dyskusji literackich. Wielu do tej pory ideowo zaangażowanych w system zaczynało zadawać sobie pytania o źródła zła, o rozmijanie się wzniosłej idei ze straszną rzeczywistością. Takie pytania stawiała sobie także jakaś część tych, którzy mieli poważny udział w instalowaniu systemu w Polsce i/lub w przeszłości należeli do KPP, mieli silne poczucie przynależności do ruchu komunistycznego, ale i poczuwali się do odpowiedzialności za jego przyszłość. Tacy ludzie mogli, a przynajmniej uważali, że mogą sobie publicznie pozwolić na więcej, zwłaszcza jeśli czuli zmianę idącą ze wschodu. Wcześniej PZPR była spajana przez bezwzględną dyscyplinę oraz jednolitą wykładnię instrukcji przekazywanych w dół

\footnotetext{
${ }^{5}$ M. Mikołajczyk, Rewizjoniści. Obecność w dyskursach okresu PRL, Kraków 2013; D. Gawin, Wielki zwrot. Ewolucja lewicy i odrodzenie idei społeczeństwa obywatelskiego 1956-1976, Kraków 2013; A. Michnik, „O roku ów!” (kilka przypuszczeń na temat Polskiego Października), w: 1956 (nieco) inne spojrzenie, red. J. Kochanowski, J. von Puttkamer, Warszawa 2016, s. 7-34; D. Rafalska, Między marzeniami a rzeczywistością. Tygodnik „Po Prostu” wobec głównych problemów społecznych i politycznych Polski w latach 1955-1957, Warszawa 2008; eadem, „Po Prostu” i jego rola w 1956 roku, w: Październik 1956 roku. Początek erozji systemu..., s. 67-94; J. Smulski, Immanentne zło komunizmu jako temat literatury i publicystyki „odwilżowej”, w: Październik '56. Odwilż i przełom w życiu literackim i kulturalnym Polski. Materiały ogólnopolskiej sesji naukowej, Rzeszów, 23-25 września 1996 r., red. A. Kulawik, Kraków 1996.
} 
przez polskiego namiestnika Józefa Stalina - Bolesława Bieruta i jego najbliższych współpracowników, Jakuba Bermana i Hilarego Minca. Po odejściu „najwyższego kapłana”, ogłoszeniu zasady „kolektywnego kierownictwa” i rozpoczęciu liberalizacji nieuniknione było zarówno osłabienie dyscypliny w partii, jak i podważenie pozycji rządzącego w Polsce „triumwiratu” jako najwyższej wyroczni w kwestiach ideologicznych. Próby narzucania jednolitej wykładni spotkały się z oporem, zaczął się spór o znaczenie i rozumienie pojęć. Równolegle rosło znaczenie nieformalnych, niezależnych od zajmowanych stanowisk, powiązań politycznych opartych na podobnych biografiach, więzach towarzyskich i kombatanckich. Długość stażu w ruchu komunistycznym, osobisty autorytet i znajomości, miejsce pobytu w czasie wojny ( $w$ okupowanym kraju czy w ZSRR) - te kryteria miały znaczenie większe niż zwykle i niekiedy były ważniejsze niż formalna hierarchia. Nie będzie dużym nadużyciem stwierdzenie, że sens wielu zmian personalnych staje się w pełni zrozumiały dopiero, gdy poznamy biografie wielu ludzi, ich drogi zawodowe, pozycje w aparacie władzy i wzajemne powiązania, które - na ile to możliwe - staram się analizować6.

W elicie PZPR dojrzewał rozdźwięk, nowa odsłona konfliktu, jaki dzielił partię komunistyczną od czasów wojny ${ }^{7}$ i był głęboko zakorzeniony w mentalności komunistów pamiętających podziały frakcyjne w KPP i wcześniejsze. Przekładał się na niespójną politykę, sprzyjał narastaniu rozprzężenia i chaosu, a tym samym postępom odwilży. Zachowane materiały pozwalają zrozumieć, dlaczego środowisko dziennikarskie zdobyło pewną dozę niezależności, upominało się o więcej, a centrum władzy i jej wojewódzkie ogniwa przejściowo straciły pewność panowania nad własnym aparatem propagandowym.

$*$

Wystarczy przejrzeć jeden rocznik prasy - 1948 - by na łamach wielu dzienników i tygodników dostrzec gwałtowność zmiany zachodzącej w następstwie stalinizacji, gdy różnorodność została zastąpiona jednolitą matrycą, a żywy język zastąpiła pompatyczna i prymitywna nowomowa ${ }^{8}$. Dla odmiany wertowanie roczników z lat 1953-1955 szybko prowadzi do wniosku, że zmiany następujące po śmierci Stalina na łamach prasy miały charakter ewolucyjny, w pierwszym okresie podskórny i były zauważalne dopiero na przestrzeni dłuższego czasu. Zmiany w Polsce następowały z dużym opóźnieniem w stosunku do Związku Sowieckiego. Na łamach polskiej prasy publikowano komunikaty agencji TASS i wstępne artykuły z „Prawdy”, w których powtarzały się hasła o kolegialności

\footnotetext{
${ }^{6}$ Za zwrócenie uwagi na tę kwestię, cenne uwagi i dyskusję dziękuję Andrzejowi Friszkemu.

${ }^{7}$ R. Spałek, U źródeł partii. Z dziejów konfliktów personalno-ideowych w kierownictwie PPR, w: Elity komunistyczne w Polsce, red. M. Szumiło, M. Żukowski, Warszawa-Lublin 2015, s. 121-153.

${ }^{8}$ A. Werblan, Stalinizm w Polsce, Warszawa 2009, s. 58.
} 
i demokracji wewnątrzpartyjnej. „Trybuna Ludu” powieliła oficjalną narrację sowieckiego kierownictwa wyjaśniającą okoliczności upadku Berii z jednym - ale istotnym - wyjątkiem. Nie przez przypadek pominęła sformułowaną w Moskwie tezę o nadrzędności partii nad aparatem bezpieczeństwa; jej opublikowanie w organie Komitetu Centralnego byłoby sygnałem do niepożądanej wówczas przez polskie kierownictwo szerszej restrukturyzacji aparatu represji ${ }^{9}$.

Wytrenowani w czytaniu między wierszami i zwracaniu uwagi na ideologiczne niuanse czytelnicy z komitetów partyjnych i redakcji widzieli więcej i przywiązywali większą wagę do zauważanych na bieżąco, pozornie drobnych zmian w prasie sowieckiej i krajowej. Z perspektywy niewyrobionego czytelnika zmiany stały się jednak wyraźnie zauważalne dopiero z perspektywy czasu, a radykalnie przyspieszyły w 1955 i zwłaszcza 1956 r. ${ }^{10}$ Dopiero porównanie zawartości wielu gazet z początku i końca 1956 r. pozwala dostrzec skalę przemian, jakie miały miejsce $\mathrm{w}$ prasie na przestrzeni tego burzliwego roku: mniej sztampy i martwej nowomowy, więcej różnorodności i żywego języka; więcej (nieco) bardziej wiarygodnych informacji. Nawet powierzchowny ogląd uzmysławia, że wiele tytułów przeszło $w$ tym okresie przyspieszoną ewolucję (a niekiedy rewolucję), modernizując swoją szatę graficzną, układ kolumn i rubryk. W odniesieniu do „Trybuny Ludu” i najpoczytniejszej stołecznej gazety - „Życia Warszawy” - nie będzie dużej przesady w stwierdzeniu, że w tym okresie oba tytuły wykonały największy skok w ukształtowaniu zasadniczego modelu, który po 1956 r. poznały następne pokolenia Polaków.

Destalinizacja w Polsce i innych krajach bloku, choć z czasem nabrała własnej dynamiki, rozpoczęła się zapewne od odczytywania przez lokalne kierownictwa intencji przywódców Kremla i podążania w ślad za nimi. Sowieckie kierownictwo, poważnie zaniepokojone kryzysowymi objawami na własnym podwórku i w państwach bloku w Europie Środkowej i Wschodniej, dało przyzwolenie na stopniową destalinizację, niekiedy nawet wywierało na swoich satelitów presję w celu uruchomienia zmian ${ }^{11}$. Wyraźne ostrzeżenie, jakim było powstanie 17 czerwca 1953 r. w NRD, zrozumiał także bierutowski „triumwirat” kierujący PZPR. Choć stalinowską politykę kontynuowano jeszcze w kilku sferach - by wspomnieć tylko o ataku na Kośció - to pierwsze, wzorowane na ZSRR, zmiany zaczęto wprowadzać w drugiej połowie 1953 r. i nieco śmielej w 1954 w wielu

\footnotetext{
${ }^{9}$ Z. Rykowski, W. Władyka, op. cit., s. 62.

${ }^{10}$ Rozmowa z Jerzym Morawskim, w: T. Torańska, Aneks, Warszawa 2015, s. 155; P. Lipiński, Bierut. Kiedy partia była bogiem, Wołowiec 2017, s. 209.

${ }^{11} \mathrm{M}$. Kramer, The early post-Stalin succession struggle and upheavals in East-Central Europe. Internal-external linkages in Soviet policy making, „Journal of Cold War Studies” 1, 1999, nr 1; F. Thom, Beria. Oprawca bez skazy, Warszawa 2016, s. 886-892; C. Békés, Europa Środkowo-Wschodnia, 1953-1956, w: Historia zimnej wojny, t. 1: Geneza, red. M.P. Leffler, O.A. Westad, Oświęcim 2017, s. 321-329.
} 
obszarach, jak polityka karna ${ }^{12}$, migracyjna ${ }^{13}$, kulturalna ${ }^{14}$ i zdrowotna ${ }^{15}$. Na ich podjęciu zaważyło nieco mniej zideologizowane i bardziej pragmatyczne podejście, rosnąca świadomość kosztów dotychczasowej polityki. Można to zilustrować przykładem jednego tylko elementu polityki kulturalnej - zarząadzania teatrem: równoczesny odpływ publiczności (nawet tej zorganizowanej) i narastający deficyt związany ze spadającymi wpływami ze sprzedaży biletów korespondował z narastającym zmęczeniem estetyką realizmu socjalistycznego. Zajmująca się tym tematem Maria Napiontkowa oceniała, że proces ostrożnych zmian liberalizacyjnych trwał mniej więcej dwa i pół roku, od 10. sesji Rady Kultury i Sztuki w lutym 1954 r. do początków 1957 r. ${ }^{16}$

Taki był kontekst ewolucji polityki prasowej. Już 17 czerwca 1953 r. w czasie narady $\mathrm{w} \mathrm{KC}$ na temat prasy i pracy ideologicznej z udziałem redaktorów naczelnych oraz sekretarzy i kierowników wydziałów propagandy komitetów wojewódzkich, w wypowiedziach ludzi kierujących wydziałami „frontu propagandowego" Artura Starewicza i Stefana Staszewskiego oraz redaktora naczelnego „Trybuny Ludu” Leona Kasmana pojawiły się akcenty krytyczne na temat stanu propagandy. Wszyscy trzej byli komunistami z dużym bagażem doświadczeń, dwaj zaangażowali się w ruch komunistyczny jeszcze w latach dwudziestych. Za przyzwoleniem Moskwy realizowali polecenie skorygowania kursu. Ich wypowiedzi nawiązywały do dyskusji na łamach prasy w ZSRR, świadczącej o narastaniu świadomości, że skuteczna propaganda musi być bardziej wiarygodna, a nie przedstawiać świat urojony ${ }^{17}$. Obok wielu rytualnych sformułowań i krytyki prasy za „brak ostrza politycznego” poświęcili wiele miejsca jej sztampowości, braku komunikatywności i oderwaniu od życia. Te same wątki pojawiły się w opublikowanym w lipcu na łamach „Nowych Dróg” artykule O niektórych błędach naszej pras $^{18}$. Irenie Tarłowskiej utkwiły w pamięci słowa Staszewskiego, który w czasie narady stwierdził, że gazeta francuskich komunistów „L'Humanité” jest lepiej, żywiej redagowana niż moskiewska „Prawda”19. W dokonanym przez Bieruta

12 A. Kutkowski, Polityka karna władz PRL w 1953 r. - jej wyznaczniki i konsekwencje, w: Yesterday. Studia $z$ historii najnowszej. Księga dedykowana prof. Jerzemu Eislerowi w 65. rocznice urodzin, red. J. Olaszek, A. Dudek, Ł. Kamiński, K. Kosiński, M. Przeperski, K. Rokicki, P. Sasanka, R. Spałek, S. Stępień, Warszawa 2017.

${ }^{13}$ D. Stola, Kraj bez wyjścia. Migracje z Polski 1949-1989, Warszawa 2010, s. 80-83.

${ }^{14}$ M. Napiontkowa, Teatr polskiego Października, Warszawa 2012.

${ }^{15}$ E. Szpak, „Chory człowiek jest wtedy jak coś go boli”. Społeczno-kulturowa historia zdrowia i choroby na wsi polskiej po 1945 r., Warszawa 2016, s. 26, 46.

${ }^{16}$ M. Napiontkowa, op. cit., s. 58-59, 74.

${ }^{17}$ M. Fik, Kultura polska po Jatcie. Kronika lat 1944-1981, Londyn 1989, s. 179.

${ }^{18}$ S. Staszewski, O niektórych błędach naszej prasy, „Nowe Drogi” 1953, nr 7.

${ }^{19}$ Relacja Ireny Tarłowskiej, 8 I 1988 r., w: Materiały pomocnicze do historii dziennikarstwa Polski Ludowej, t. 17, red. A. Słomkowska przy współpracy D. Mikołajczyk-Grzelewskiej, Warszawa 1992, s. 232. 
podsumowaniu dyskusji padła uwaga: „oczywiście słusznie, gdyby było więcej krytycznej oceny naszej pracy, to może by to pomogło naszej prasie, za mało jest tej oceny, krytyki”20. To ostatnie słowo - krytyka - zaczęło coraz częściej pojawiać się w partyjnych referatach i wypowiedziach, by z czasem wejść na stałe do repertuaru słów-kluczy w tym okresie, na równi z pojęciami „kolegialność” i - z czasem - „demokratyzacja”.

Te terminy pojawią się w tekście wielokrotnie, co może być przyczyną nieporozumień wynikających ze współczesnego nadawania im innych znaczeń niż w przeszłości, w odmiennej rzeczywistości politycznej i społecznej. Na szczególną uwagę zasługuje zwłaszcza pojęcie „demokratyzacji” („polityki demokratyzacji”). Może bowiem sugerować ewoluowanie reżimu w stronę jakiejś formy demokracji, choć $\mathrm{w}$ istocie chodziło o stopniowe modyfikowanie, pewne zracjonalizowanie i rozluźnienie totalitarnych reguł jego funkcjonowania, co do pewnego stopnia uzasadnia posługiwanie się terminem „liberalizacja”. Program i przewidywany zasięg owej liberalizacji nie został dookreślony i pozostał raczej mgławicowy, co było jej pierwszą cechą. Jakub Karpiński zauważył, że wyliczenia z uchwały przyjętej przez VII plenum KC w 1956 r. pozwalają zorientować się, co rozumiano przez pojęcie demokratyzacji i gdzie widziano jej zastosowania. Miała ona polegać na dopuszczeniu do działania instytucji takich jak sejm, rząd, ministerstwa i rady narodowe, miała polegać na praworządności i jawności życia politycznego, wolności krytyki i umożliwienia robotnikom wpływu na sytuację w zakładach pracy ${ }^{21}$. Drugą jej cechą była znacząca dysproporcja między częstotliwością pojawiania się terminu „demokratyzacja” w oficjalnym języku władzy, a rzeczywistym zasięgiem i jakością zmian zachodzących $\mathrm{w}$ systemie. Po trzecie wreszcie, ze względu na mgławicowość tego pojęcia, bardziej zasadne wydaje się rozpatrywanie konkretnych decyzji i zmian: czy były rezultatem podejścia liberalizacyjnego, czy też dogmatycznego.

Od narad w Lublinie, Stalinogrodzie (Katowicach) i Kielcach w sierpniu 1953 r. Wydział Prasy i Wydawnictw KC zaczął serię spotkań z dziennikarzami prasowymi i radiowymi w miastach wojewódzkich, które miały być poświęcone realizacji wytycznych Bieruta $\mathrm{z}$ narady czerwcowej. W sprawozdaniach pisano sztampowo: o ostrożnych głosach krytycznych wobec rzekomego „odpolitycznienia" pracy redakcji, braku kontroli komitetów wojewódzkich nad gazetami, funkcjonowania wydziału. Cykl tych spotkań na przełomie września i października zamknęła seria narad $\mathrm{z}$ redakcjami pism warszawskich, zdominowanych już przez bardziej wiarygodne i nieco bardziej krytyczne wypowiedzi na temat stanu prasy i propagandy. W sprawozdaniach $\mathrm{z}$ ich przebiegu odnotowano m.in.: „Wszystkie

${ }^{20}$ AAN, KC PZPR, 237/V/30, Stenogram z narady, 17 VI 1953 r., k. 68-79, 86-99, 105-114, 138; ibidem, 237/XIX/10, Sprawozdanie z pracy Sektora Prasy w czerwcu 1953 r., k. 53-54.

${ }^{21}$ J. Karpiński, Porcja wolności (Październik 1956), w: idem, Wykres gorączki. Polska pod rządami komunistycznymi, Lublin 2001, s. 88. 
uwagi, jakie padły w naradach o sprawie Niemiec, sprowadzają się do krytyki prasy za to, że nie odpowiada ona na sprawy nurtujące opinię publiczną”; „W redakcji «Expressu» mówiono, że w bardzo wielu wypadkach gazeta pracuje w myśl zasady «sztuka dla sztuki», nie troszcząc się należycie o skuteczność swej pracy. W redakcji «Życia Warszawy» podnoszono, że zespół zaczyna dopiero patrzeć na gazetę oczyma czytelnika”; „W redakcjach odczuwa się silnie potrzebę rozszerzenia tematyki, przełamania szranek «produkcyjnej» jednostronności”; „O reportażach $\mathrm{w}$ «Świecie» mówiono, że nie kłamią, ale "prawda ich jest niepełna»"22. Zatem dość ostrożnie i nie wprost, ale poruszano kwestię zakłamywania rzeczywistości przez prasę, potrzebę zerwania z językiem niezrozumiałym dla ludzi i poszukiwania nowych, bardziej atrakcyjnych form publicystycznych.

$\mathrm{Tu}$ niezbędne są dwa zastrzeżenia. Po pierwsze, $\mathrm{z}$ lektury przywoływanych w tekście głosów krytycznych wobec stanu propagandy czytelnik może odnieść wrażenie napięcia narastającego w środowisku dziennikarskim już w 1953 r. Jest to wrażenie mylne, cytowane wypowiedzi tonęły bowiem w powodzi ideologicznej nowomowy wypełniającej ówczesne narady i spotkania, z której zostały wyłowione przez autora niniejszego tekstu. Nie były też początkowo wynikiem autorefleksji środowiska dziennikarskiego buntującego się przeciw roli prasy jako propagandowego narzędzia partii. Były możliwe - tak jak w innych obszarach - dzięki impulsowi płynącemu z góry. Jak już wspomniano, w czasie przywoływanej narady z czerwca 1953 r. wątki krytyczne znalazły się w wypowiedziach ludzi rządzących „frontem propagandowym”, co było czytelnym sygnałem, który zachęcał do bardziej otwartego dzielenia się przemyśleniami na temat nieskuteczności dotychczasowej propagandy.

Po drugie, pamiętać należy o specyficznej perspektywie dokumentów, na podstawie których dziś rekonstruujemy funkcjonowanie polityki prasowej, w tym przebieg poszczególnych narad partyjnych i treść wypowiedzi. To przede wszystkim perspektywa centrum władzy, odpowiednich komórek Komitetu Centralnego, $\mathrm{z}$ jednej strony pozwalająca wejrzeć $\mathrm{w}$ mechanikę zarządzania mediami, następujące zmiany, dostrzegane $\mathrm{z}$ centrum zagrożenia, ale $\mathrm{z}$ drugiej strony wypaczająca obraz już na poziomie wysoce zideologizowanego i zakłamującego rzeczywistość języka. Apele o podejmowanie na łamach prasy spraw nurtujących opinię publiczną nie oznaczały - co oczywiste - rzeczywistego uwolnienia prasy z więzów, ale ich rozluźnienie, czyli ograniczenie funkcji indoktrynacyjno-mobilizacyjnej. Odnotowywane przez KC okresowe „nasilenie” bądź „osłabienie” krytyki prasowej w 1955 r. nabiera właściwych rozmiarów dopiero gdy weźmiemy do ręki stare roczniki i uświadomimy sobie niewielką skalę owego „nasilenia”/,osłabienia”, którą przeciętni czytelnicy zapewne mogli łatwo przeoczyć. Przejrzenie

22 AAN, KC PZPR, 237/XIX/10, Sprawozdanie Sektora Prasy (pierwsza połowa października), k. 66, $68,69,70$. 
archiwalnych numerów „Trybuny Ludu” pod kątem zweryfikowania zarzutów sformułowanych przez Biuro Polityczne pod adresem pisma pod koniec $1955 \mathrm{r}$. prowadzi do uświadomienia sobie wagi nieuchwytnego dziś kontekstu, umiejętności czytania między wierszami i arbitralności zarzutów. Wreszcie zestawienie krytycznych uwag i postulatów zmian padających w czasie partyjnych narad z zawartością łamów prasy wiedzie do wniosku, że były to dwie niemal odrębne rzeczywistości.

Kuluarowe dyskusje na temat panującej w prasie „drętwoty” zaistniały na forum publicznym w dniach 28 i 29 listopada 1953 r. w czasie walnego zebrania warszawskiego oddziału Stowarzyszenia Dziennikarzy Polskich zorganizowanego z inspiracji KC PZPR. Ton obradom nadało krytyczne przemówienie wygłoszone na wstępie przez ówczesnego przewodniczącego zarządu głównego SDP i redaktora naczelnego „Życia Warszawy”, Henryka Korotyńskiego, który zachęcał dziennikarzy do zmian. „Ach, jakież ja wtedy wygadywałem herezje!” - z przesadą wspominał po latach, skądinąd nie ukrywając, że miał zachętę z Komitetu Centralnego ${ }^{23}$. Więcej, nawiązywał do niedawnych referatów Nikity Chruszczowa i Gieorgija Malenkowa z narady z dziennikarzami w Moskwie poświęconej „krytyce bezkonfliktowości”24. W podobnym tonie wypowiedział się też Jerzy Putrament w czasie październikowego IX plenum KC PZPR w 1953 r. ${ }^{25}$

Powojenna kariera Korotyńskiego była typowa dla ludzi, którzy z różnych powodów - często konformizmu bądź strachu - oddali swe pióra i intelekt w służbę nowego ustroju. Wywodził się ze znanej dziennikarskiej rodziny, był synem i wnukiem cenionych dziennikarzy i jeszcze przed 1939 r. sam zaistniał $\mathrm{w}$ prasie sanacyjnej. $\mathrm{W}$ czasie wojny redagował przeglądy prasy ukazujące się w prasie konspiracyjnej Departamentu Informacji Delegatury Rządu RP, a po aresztowaniu przez Niemców przeszedł przez Pawiak, Auschwitz i Buchenwald. Wielu ludzi o podobnej biografii w komunistycznej Polsce nie mogło kontynuować kariery dziennikarskiej, wielu trafiło w ręce UB, ale nie był to przypadek Korotyńskiego. Po krótkim epizodzie w „Dzienniku Ludowym” przeszedł do popularnej popołudniówki „Wieczór Warszawy”, w którym szybko objął stanowisko redaktora naczelnego. Formalny akces do PPR w lutym 1948 r. z rekomendacją komunistów o długim stażu i mocnej pozycji: Pawła Hoffmana i Wiktora Borowskiego, otworzył mu drogę do błyskawicznej kariery: stanowiska redaktora naczelnego Agencji Publicystyczno-Informacyjnej, „Rzeczpospolitej”, a od 1951 r. - czyli w apogeum stalinizmu - „Życia Warszawy”. Pozostał nim, z krótką przerwą w 1957 r., do 1972. Równolegle szybko piął się w górę w dziennikarskich organizacjach zawodowych, grając $\mathrm{w}$ nich pierwszoplanowe role. $\mathrm{W}$ tym

\footnotetext{
${ }^{23}$ H. Korotyński, Trzy czwarte prawdy. Wspomnienia, Warszawa 1987, s. 132-133.

${ }^{24}$ M. Fik, op. cit., s. 188.

${ }^{25}$ Dyskusja na IX plenum KC PZPR, „Nowe Drogi” 1953, nr 10, s. 155.
} 
związku korzyści były obopólne: w zamian za przymknięcie oka na sanacyjną i konspiracyjną przeszłość komuniści pozyskiwali utalentowanego i cenionego w środowisku dziennikarza, który sam widział się w roli tzw. bezpartyjnego bolszewika ${ }^{26}$. W czasie odwilży „apolityczni” fachowcy jego pokroju, którzy z reżimem związali swoją karierę, nie będą raczej skłonni do jednoznacznego zaangażowania na rzecz zmian, będą częściej meandrowali, próbując dostosować się do szybko zmieniających się okoliczności.

Korotyński zaczął od stwierdzenia, że w środowisku od dawna narastało niezadowolenie z sytuacji w prasie, ale dotąd nie było atmosfery sprzyjającej krytyce. Referował treść narad redakcyjnych, w czasie których krytykowano „nadmierny, «urzędowy» optymizm w pracy wielu gazet, zjawisko lukrowania nie zawsze słodkiej prawdy i przyjmowania własnych życzeń za rzeczywistość, podawano przykłady wulgaryzowania i upraszczania rzeczywistości”. Mówiąc o rażącym rozdźwięku „między trudnościami i nastrojami a entuzjastyczno-radosnym tonem” niemal otwarcie przyznawał, że prasa nie spełnia podstawowego oczekiwania czytelników, którzy - po prostu - chcą być dzięki gazetom poinformowani. To zaś prowadziło go do mocnej konkluzji: „Wynik jest żałosny: czytelnik też nie chce. Mianowicie nie chce czytać takich artykułów takich dziennikarzy".

Jakie widział drogi naprawy? Oczekiwał zostawienia dziennikarzom szerokiego marginesu samodzielności, szanowania indywidualności pisarskiej. Nie dając carte blanche na przyszłość, za szkodliwą i groźną uznał dotychczasową sytuację, w której obawa przed błędem politycznym paraliżuje samodzielną myśl, tłumi indywidualność i oryginalność autorską. Oczekiwał od redakcji atmosfery dyskusji, poszukiwania, niepokoju, a od dziennikarzy postawy aktywisty, „który ingeruje, wtrąca się do każdego objawu życia”, „nie pozostaje obojętny”, „który nie godzi się ze złem, ze świństwem, z krzywdą, z głupotą”, „który żyje myślą, jak naprawić, jak ulepszyć, jak pchnąć naprzód, jak wyjaśnić, przekonać [...]”. Trudno nie zwrócić uwagi na zabawny - z dzisiejszej perspektywy - paradoks: tak zakreślone oczekiwania wydają się stworzone z myślą o młodych, ideowych, radykalnie lewicowych dziennikarzach z redakcji „Po Prostu” i „Sztandaru Młodych”, którzy nadali ton październikowemu dziennikarstwu. W 1953 r. nikt jednak nie sięgał wyobraźnią tak daleko, a w 1956 r. zapewne nikt już nie pamiętał tych słowach.

Korotyński miał wiele racji, postrzegając to zebranie jako jeden $\mathrm{z}$ najwcześniejszych sygnałów zmian. Zachęcone kursem wyznaczonym przez prominentnego mówcę, w czasie dyskusji 24 osoby krytykowały stan aktualny, niektóre dzieliły się pomysłami na naprawę. Rangę spotkania podniósł, podsumowujący dyskusję z ramienia partii, zastępca kierownika Wydziału Prasy i Wydawnictw KC Jerzy Kowalski, zauważając, że w gruncie rzeczy obradowano nie tylko nad

${ }^{26}$ AAN, KC PZPR, CK XX/18699, Akta osobowe Henryka Korotyńskiego, k. 6-17; E. Ciborska, Leksykon polskiego dziennikarstwa, Warszawa 2000, s. 258-259. 
sytuacją w prasie, ale polskim życiem politycznym i kulturalnym ${ }^{27}$. Obradom i dyskusji, ocenzurowanej z bardziej pikantnych fragmentów ${ }^{28}$, poświęcono cały numer branżowego miesięcznika SDP „Prasa Polska”29. Na jego łamach stopniowo zaczęły ukazywać się artykuły pisane inaczej, żywiej, próbujące realizować postulat zmian ${ }^{30}$.

W tym czasie symptomy odwilży pojawiły się w środowisku ludzi kultury i na łamach pism literackich. Pod koniec listopada 1953 r. w „Nowej Kulturze” ukazał się wyróżniający się autentycznością anonimowy Pamiętnik uczennicy, który zaszokował czytelników, wywołał dyskusję na łamach prasy i oburzył kierownictwo partii, co skończyło się wezwaniem członków redakcji przed oblicze Jakuba Bermana ${ }^{31}$. W księgarniach ukazał się tom szkiców Zygmunta Kałużyńskiego z wrażeniami z podróży na Zachód, rozchwytywany przez czytelników, uznany $\mathrm{z}$ czasem za znaczące przełamanie zasady przemilczania $\mathrm{w}$ miejsce polemik. W grudniu 1953 r. artykuł krytyka literackiego i teatralnego Ludwika Flaszena (który jako jeden z pierwszych jeszcze w 1952 r. pisał o schematyzmie literatury socrealistycznej), teraz otworzył dyskusję na temat funkcji literatury, dyskusję, która podważyła jej ideologizację. Odpowiedzi udzielane w publikowanej w 1954 r. ankiecie "Nowej Kultury” Pisarze wobec dziesięciolecia, pytającej o dotychczasowy dorobek literacki Polski „ludowej”, wykraczały poza schemat socrealistyczny ${ }^{32}$. Liberalny kurs wobec literatury znalazł potwierdzenie na łamach partyjnego pisma teoretycznego ${ }^{33}$. W kwietniu 1954 r. Jerzy Putrament opublikował w „Przeglądzie Kulturalnym” artykuł, w którym doszukiwano się akcentów krytycznych wobec polityki kulturalnej ZSRR ${ }^{34}$. W czasie zjazdu Związku Literatów Polskich w czerwcu 1954 r. Wiktor Woroszylski, który od 1952 r. przebywał w „ojczyźnie światowego proletariatu”, poznał jej realia i pozbył się złudzeń,

${ }^{27}$ Kowalski, który w ramach nadzoru KC uczestniczył w posiedzeniach prezydium SDP, według Korotyńskiego „zachowując umiar, pchał do przodu”, H. Korotyński, op. cit., s. 133-134.

${ }^{28} \mathrm{~W}$ jednym $\mathrm{z}$ usuniętych fragmentów padło stwierdzenie, że przyjaźni polsko-radzieckiej nie umacnia ten redaktor, który wiadomości o meczu przegranym przez polską drużynę daje tytuł: Zwycięstwo piłkarzy radzieckich, ibidem.

29 „Prasa Polska” 1953, nr 11.

${ }^{30}$ Np. Nuda Redaktorem. O aktywniejsza akcję aktywu, „Prasa Polska” 1954, nr 1-2, s 2-9. W numerze z kwietnia 1954 r. ukazała się cała seria artykułów: L. Wysznacki, Kilka uwag o stanie reportażu (s. 3-5); Dziennikarski dialog (s. 7-8); S. Kozłowski, O „Dookoła Świata” - tym razem na poważnie... (s. 9-10); E. Strzelecki, O właściwe miejsce dla sprawozdawczości sportowej, s. 3-5.

${ }^{31}$ Pamiętnik uczennicy, „Nowa Kultura” 1953, nr 48, s. 3-4; T. Chrząstek, Na kulturalnym froncie. Analiza zawartości tygodnika „Nowa Kultura” 1950-1963, Warszawa 2016, s. 158-160; T. Mielczarek, Kultura i polityka. Kultura, życie umysłowe, media 1944-1989, Warszawa 2010, s. 277.

${ }^{32}$ M. Fik, op. cit., s. 187-189, 192.

33 O wielka sztukę Polski Ludowej, „Nowe Drogi” 1954, nr 5; Nauczanie literatury polskiej w szkołach średnich, „Nowe Drogi” 1954, nr 8.

${ }^{34}$ Notatka w sprawie artykułu trafiła na biurko Jakuba Bermana. AAN, KC PZPR, VII/13 załączniki do protokołów Sekretariatu i BP za 1954. 
w napięciu relacjonował toczące się w ZSRR odwilżowe dyskusje literackie ${ }^{35}$. Jego przemówienie, ocenzurowane, ukazało się na łamach „Nowej Kultury”36. Pismo zamieściło też fragmenty wypowiedzi z zebrania organizacji partyjnej Oddziału Warszawskiego ZLP, w czasie którego krytykowano dotychczasową pracę oraz wyczekiwanie na rezultaty dyskusji w ZSRR i decyzje władz ${ }^{37}$. We wrześniu $1954 \mathrm{r}$. o zwrocie w polityce kulturalnej i potrzebie śmiałego i szczerego sięgnięcia do przyczyn błędów mówił w czasie sesji Rady Kultury i Sztuki minister kultury Włodzimierz Sokorski. Najważniejsze opiniotwórcze pisma literackie, jeszcze w 1954 r. wypełnione oficjalnymi sprawozdaniami i referatami, od początku 1955 r. zaczęły odważniej rozliczać się z przeszłością ${ }^{38}$.

Obradujący w marcu 1954 r. II zjazd PZPR, odbywający się już w zmienionych warunkach, raczej nie spełnił oczekiwań środowiska liczącego na wyraźniejsze przyzwolenie na zmiany w prasie. O tyle, że w odnoszącej się do prasy części referatu wygłoszonego przez Bieruta ponownie znalazła się krytyka „schematyzmu”, ubóstwa i skostnienia języka propagandy i zaakcentowano potrzebę zbliżenia prasy do oczekiwań czytelników - tak, jak je wówczas sobie wyobrażano. Po zakończeniu zjazdu Bierut spotkał się z dziennikarzami i literatami w Belwederze, podkreślając znaczenie tego, by słowa partii trafiały do narodu ${ }^{39}$. Mimo że funkcja prasy jako pasa transmisyjnego polityki partii wobec społeczeństwa pozostawała dogmatem, uwag Bieruta nie należy lekceważyć. Jak zauważył Andrzej Kozieł, akcentując potrzebę dostosowania propagandy do odbiorców, Bierut mimowolnie stawiał pod znakiem zapytania dotychczasowy pewnik, że to partyjny decydent najlepiej wie, czego potrzebuje społeczeństwo ${ }^{40}$.

By ów pas transmisyjny działał sprawniej, Sekretariat KC postanowił co najmniej dwa razy w miesiącu organizować w Wydziale Propagandy i Agitacji KC narady z redaktorami prasy i radia ${ }^{41}$. Dostrzeżono wreszcie istnienie związku między atrakcyjnością przekazu i skutecznością propagandy. Przy zachowaniu dotychczasowego systemu kontroli i kierowania prasa miała teraz być inaczej redagowana, bardziej atrakcyjna i zróżnicowana. Symboliczny dla ewolucji prasy i poszukiwania bardziej atrakcyjnej formy był ukazujący się od początku 1954 r. kolorowy ilustrowany magazyn „Dookoła Świata”, który pokazywał czytelnikom niedostępny świat zza „żelaznej kurtyny” i rzadko zamieszczał treści o charakterze stricte

\footnotetext{
35 A. Friszke, Wiktor Woroszylski. Polityka i literatura, w: W. Woroszylski, Dzienniki, t. 1: 1953-1982, red. A. Dębska, oprac. przypisów K. Rokicki, B. Kaliski, A. Dębska, Warszawa 2017, s. 22-23.

${ }^{36}$ W. Woroszylski, Ostrzegam przed bobrami, „Nowa Kultura” 1954, nr 26.

37 „Nowa Kultura” 1954, nr 45.

38 T. Mielczarek, Liberałowie i rewizjoniści. Z dziejów „Przegladu Kulturalnego” (1952-1963), „Kieleckie Studia Bibliologiczne” 2000, nr 5, s. 102-104.

${ }^{39}$ Spotkanie w Belwederze, „Prasa Polska” 1954, nr 3, s. 1.

${ }^{40}$ A. Kozieł, Polityka prasowa w 1956 roku..., s. 52.

${ }^{41}$ AAN, KC PZPR, 237/VIII/214, Uchwała Sekretariatu KC, 1954, k. 43.
} 
propagandowym ${ }^{42}$. Pismo było rozchwytywane z kiosków w ciągu kilku godzin, czytelnicy prosili sprzedawców o odkładanie numerów i wymieniali się tymi, których nie udało im się zdobyćc ${ }^{3}$. W lipcu 1954 r., co dwa tygodnie zaczęło się ukazywać „Przedpole” - dodatek społeczno-kulturalny do „Sztandaru Młodych”, interdyscyplinarne czasopismo adresowane do twórców kultury i jej odbiorców, otwarte na wszystkie rodzaje sztuki. Pismo, pod pewnymi względami będące prekursorem czasopism odwilżowych, przestało się ukazywać po dwunastu numerach. Paradoksalnie, tuż przed przyspieszeniem odwilży w Polsce i zmianą oblicza prasy ${ }^{44}$.

Kierownictwo partii nie dostrzegało sprzeczności nowego kursu publicystyki z kontynuowaną, choć już nie tak bezrefleksyjnie, dotychczasową „rewolucyjną” polityką kadrową. Mimo dotkliwych braków kadrowych, z zawodu w dalszym ciągu usuwano starszych dziennikarzy z jeszcze przedwojennym stażem, nie bacząc na wyrobione pióra i bogate doświadczenie. Byli zastępowani młodymi absolwentami studiów, szkół partyjnych, kursów dziennikarskich, którzy w wielu redakcjach stanowili już trzon zespołu ${ }^{45}$. Na przykład usunięcie w pierwszej połowie 1954 r. „rutyniarzy” z prasy sportowej i zastąpienie ich młodymi dziennikarzami przyniosło - jak oceniano - podniesienie poziomu i atrakcyjności redakcji i działów sportowych ${ }^{46}$. Władze wychowały sobie zastępy nowych, lojalnych dziennikarzy. Paradoksalnie w 1956 r. okazało się, że to właśnie młodzi ludzie, uformowani już w komunistycznej rzeczywistości, z głowami umeblowanymi marksistowską ideologią, najsilniej przeżyli jej kryzys; idealistycznie próbując zmienić rzeczywistość, z którą trudno było im się pogodzić, nadali kierunek październikowemu dziennikarstwu.

Jeszcze w przeddzień II zjazdu PZPR postanowiono, że należy odejść od nacisku administracyjnego w dystrybucji prasy partyjnej ${ }^{47} \mathrm{z}$,Trybuną Ludu” na czele i ograniczyć prenumeratę zakładową na rzecz innych form dystrybucji ${ }^{48}$. $\mathrm{W}$ rezultacie $\mathrm{w}$ ciągu roku nakład gazet i czasopism partyjnych w prenumeracie zakładowej spadł z 66,4\% w pierwszym kwartale 1954 r. do 46,9\% w pierwszym kwartale 1955 r., co zapoczątkowało trend ${ }^{49}$. Zamierzano rozbudować sieć

\footnotetext{
${ }^{42}$ W. Władyka, Na czołówce. Prasa w październiku..., s. 20-23; Z. Rykowski, W. Władyka, op. cit., s. 76-81.

${ }^{43}$ Relacja Tomasza Szaroty z 2018 r.

${ }^{44}$ Szerzej zob. A. Zawistowski, Dwutygodnik „Przedpole” i jego krag, w: Nie tylko „Po Prostu”. Prasa polska $w$ dobie odwilzy 1955-1958, red. M. Przeperski, P. Sasanka [w druku].

${ }^{45}$ AAN, KC PZPR, 237/VIII/363, Biuletyn nr 11 Sektora Prasy, 29 VI 1955 r., k. 106-108.

${ }^{46}$ AAN, KC PZPR, 237/VIII/362, Notatka w sprawie pracy z redakcjami (czerwiec 1954), k. 63-66.

${ }^{47}$ Termin „prasa partyjna” jest nieostry. W praktyce jej formalnym wyróżnikiem był podtytuł „organ KC PZPR” lub „organ KW PZPR”. E. Grygo, Z problematyki kierownictwa prasa PZPR w latach 1948-1959, „Kwartalnik Historii Prasy Polskiej” 1984, nr 1, s. 69.

${ }^{48}$ AAN, KC PZPR, V/27, Protokół posiedzenia Sekretariatu Biura Organizacyjnego, 19 II 1954 r., k. 68-69.

49 AAN, KC PZPR, 237/VIII/363, Biuletyn Sektora Prasy nr 10, 20 VI 1955 r., k. 97.
} 
etatowych korespondentów głównego organu partii i - na wzór „Prawdy” - częściowo ujednolicono wydania „Trybuny”, do tej pory ukazującej się w wielu mutacjach. Zgodnie z propozycją Wydziału Propagandy i Agitacji KC nowy kierunek miał zostać „przeniesiony” do środowiska w czasie planowanego na maj $1954 \mathrm{r}$. zjazdu SDP, krytyczne narady na temat propagandy miały się też odbyć w czerwcu i lipcu w terenie na poziomie komitetów powiatowych/miejskich PZPR ${ }^{50}$.

W przededniu i w czasie II zjazdu PZPR Bierut zrealizował oczekiwania Moskwy dotyczące reorganizacji gremiów decyzyjnych partii i zmian personalnych będących konsekwencją nowej fali kursu antysemickiego w ZSRR. Grupę towarzyszy żydowskiego pochodzenia przeniesiono na mniej eksponowane stanowiska, co oznaczało wiele zmian na kluczowych stanowiskach „frontu propagandowego" w Komitecie Centralnym i w najważniejszych redakcjach. Seria zmian rozpoczęła się w grudniu 1953 r. od „Trybuny Ludu”. Redagującego ją od początku Leona Kasmana, działacza Kominternu i zaufanego człowieka Moskwy zastąpił Władysław Matwin, wywodzący się z młodszego pokolenia komunistów ${ }^{51}$. Urodzony w 1916 r., zdążył należeć do KPP przed jej likwidacją, w czasie wojny był w ZSRR, gdzie m.in. działał w Związku Patriotów Polskich. Po 1945 r. pracował jako I sekretarz komitetu wojewódzkiego PPR/PZPR we Wrocławiu i komitetu warszawskiego, z przerwą na przewodniczenie zarządowi głównemu ZMP.

W wyniku roszad w Komitecie Centralnym Stefan Staszewski przeszedł z funkcji kierownika Wydziału Prasy i Wydawnictw na stanowisko o marginalnym znaczeniu: pełnomocnika KC ds. usprawnienia działalności Państwowych Ośrodków Maszynowych, a Artur Starewicz zamienił stanowisko kierownika Wydziału Propagandy i Agitacji KC na funkcję sekretarza w centrali związków zawodowych. Kierowane przez nich wydziały połączono w jeden, który tym samym objął nadzór nad całością spraw propagandowych, prasy, wydawnictw, radia i filmu a także przejęty z Wydziału Kultury - sektor kulturalno-oświatowy ${ }^{52}$.

Na czele tego „superwydziału” stanął Jerzy Morawski - „nieobciążony etnicznie”, podobnie jak Matwin wywodzący się z młodszego, mniej dogmatycznego pokolenia komunistów. Co ważne, nie spędził wojny w ZSRR, ale w okupowanym kraju, gdzie działał w komunistycznej młodzieżówce, redagował prasę, a od lipca 1944 r. był członkiem sekretariatu KC PPR - a zatem miał już jakąś pozycję.

${ }^{50}$ AAN, KC PZPR, VII/12, Notatka w sprawie zjazdu SDP, 26 IV 1954 r., k. 13-15; ibidem, Do I sekretarza KW w sprawie plenarnych posiedzeń KP na temat propagandy i agitacji, k. 123-124.

${ }^{51}$ M. Szumiło, Roman Zambrowski 1909-1977. Studium z dziejów elity komunistycznej w Polsce, Warszawa 2014, s. 312-314; P. Lipiński, op. cit., s. 178.

52 Taka struktura organizacyjna przetrwała do listopada 1955 r., gdy nadzór nad prasą, wydawnictwami i radiem przejął Wydział Prasy, Radia i Wydawnictw. Został ponownie włączony do Wydziału Propagandy i Prasy w sierpniu 1956 r. Do kolejnych zmian doszło już po październikowym przesileniu politycznym w listopadzie tego roku, gdy utworzono Biuro Prasy i Wydział Propagandy i Agitacji. W. Janowski, A. Kochański, Informator o strukturze i obsadzie personalnej centralnego aparatu PZPR 1948-1990, red. K. Persak, Warszawa 2000, s. 96. 
Po 1945 r. należał do Związku Walki Młodych, Związku Młodzieży Polskiej i był sekretarzem KW PZPR w Poznaniu, a od 1952 r. zastępcą Starewicza. Objęcie samodzielnego kierownictwa wydziału odpowiedzialnego za cały „front propagandowy" było dla niego awansem i zarazem dużym wyzwaniem ${ }^{53}$. Formalnie podlegał Edwardowi Ochabowi jako sekretarzowi KC nadzorującemu kulturę, naukę i propagandę. Nieformalnie także Jakubowi Bermanowi, który zgodnie z zaleceniami Moskwy został przesunięty na boczny tor i objął funkcję wicepremiera, ale pozostał w Biurze Politycznym i zachował znaczne wpływy. Morawski kontaktował się także z Bierutem i Romanem Zambrowskim.

Dla sytuacji w mediach znaczenie miała także dymisja Hilarego Minca z funkcji przewodniczącego Państwowej Komisji Planowania Gospodarczego, którego Bierut również utrzymał w Politbiurze i na stanowisku wicepremiera. Miesiąc później, w kwietniu 1954 r. jego żona Julia odeszła ze stanowiska w Polskiej Agencji Prasowej, którą przez wiele lat - ze względu na pozycję męża, ale też własny staż partyjny - de facto kierowała jako redaktor naczelny i zastępca dyrektora ${ }^{54}$.

Kilka miesięcy później zmiana nastąpiła także w Polskim Radiu. Kierował nim Romuald Gadomski, sprawdzony komunista z bardzo długim stażem. Urodził się w 1905 r., działał w KPRP/KPP od 1922 r., był wielokrotnie więziony za działalność komunistyczną, po 1939 r. współpracował z polskojęzycznym „Sztandarem Wolności” w Mińsku, po wojnie w latach 1946-1950 był wicedyrektorem Departamentu V MBP (zastępcą Julii Brystygierowej), w latach 1950-1954 wiceprezesem Centralnego Urzędu Radiofonii, a następnie Komitetu ds. Radiofonii „Polskie Radio” i w 1951 r. zastąpił na stanowisku prezesa Wilhelma Billiga ${ }^{55}$. We wrześniu 1954 r. odszedł na stanowisko redaktora naczelnego „Gazety Poznańskiej”. Jego miejsce zajął Tadeusz Galiński, młodszy od swojego poprzednika, dla którego był to dopiero pierwszy znaczący awans w karierze politycznej. Urodzony w 1914 r., w PPR od 1945 r., do tej pory był redaktorem naczelnym „Trybuny Dolnośląskiej”, a od 1948 r. „Trybuny Robotniczej” w Katowicach, dziennika o nakładzie 1,5 mln egzemplarzy, ówcześnie największym w kraju.

Zjazd Stowarzyszenia Dziennikarzy Polskich zgodnie z wcześniejszymi planami odbył się 15 i 16 maja 1954 r. Aktualny kurs wyznaczały wprowadzające

${ }^{53}$ AAN, CK PZPR, CK/VII-1018, teczka osobowa Jerzego Morawskiego; Rozmowa z Jerzy Morawskim, w: T. Torańska, op. cit., s. 150-151; P. Lipiński, op. cit., s. 211.

${ }^{54}$ Dyrektorem Polskiej Agencji Prasowej od sierpnia 1951 r. do września 1956 r. był Lucjusz Domański, od października 1949 r. wiceminister rolnictwa. E. Ciborska, Polska Agencja Prasowa. Tradycja i współczesność, „Rocznik Historii Prasy Polskiej” 1998, nr 1-2, s. 176-177.

${ }^{55}$ Był w grupie komunistów, którzy z polecenia władz sowieckich opuścili ZSRR w szeregach armii gen. Andersa. J. Pietrzak, Działalność komunistów wśród polskiego wychodźstwa na Bliskim Wschodzie w świetle materiałów kontrwywiadu Polskich Sił Zbrojnych (1944 r.), „Dzieje Najnowsze” 2006, nr 3, s. 122-123; idem, Sytuacja polityczna w Polsce w latach 1944-1947 w świetle „Biuletynu Wolnej Polski” - pisma Związku Patriotów Polskich na środkowych Wschodzie, „Przegląd Nauk Historycznych" 2008, nr 1, s. 106-107. 
przemówienia Morawskiego, a zwłaszcza przewodniczącego zarządu głównego - Korotyńskiego. Z jednej strony nawiązywały one do wytycznych II zjazdu, $\mathrm{z}$ drugiej korygowały je, co miało związek z napływającymi już do KC informacjami. Pisma i skargi z terenu świadczyły o rosnących napięciach. Powodował je stopniowo zmieniający się ton publicystyki prasowej, która - zgodnie z zaleceniem „bliżej ludzi” - podejmowała próby wycinkowego, ale jednak bardziej wiarygodnego opisu uciążliwości życia codziennego. „Zbyt naturalistyczna” lub - jak to określano - „jednostronna” krytyka wywoływała alergiczne reakcje stalinowskiego aparatu władzy w terenie, głęboko zaniepokojonego naruszeniem dotychczasowego status quo, stojącego teraz przed perspektywą tłumaczenia się na łamach prasy lub zwierzchnikami „z Warszawy” z ujawnianych lokalnie i oficjalnie tępionych patologii ${ }^{56}$.

Dlatego w referacie Korotyńskiego równolegle $\mathrm{z}$ wezwaniem do podnoszenia atrakcyjności prasy pojawił się wątek zbyt ostrej krytyki. „Tymczasem ostatnio namnożyło się w prasie niepokojąco dużo przykładów krytyki nieodpowiedzialnej - mówił. - Tu i ówdzie drukuje się materiały krytyczne bez sprawdzenia rzeczywistego stanu rzeczy i krytykuje się ludzi bogu ducha winnych. [...] Wtedy powstaje zjawisko krytyki dla krytyki, dla efektu, dla sensacji, dla sportu. A nam nie to jest potrzebne, lecz cnota roztropności w krytyce. Krytyka nieprzemyślana czy lekkomyślna prowadzić może - już i takie były jej nieudane owoce - do uderzenia w same podstawy naszej polityki, w same zasady naszej gospodarki" ${ }^{77}$.

W ten sposób narodziło się mgławicowe pojęcie konstruktywnej, względnie odpowiedzialnej krytyki. Powinna ona mieć walory „wychowawcze”, a nie być wyłącznie negatywna. Powinna mieścić się w dozwolonych przez władze wąskich ramach, nie wyciągać zbyt daleko idących wniosków (na temat systemowych przyczyn patologii), mieć oparcie w faktach, raczej unikać wskazywania konkretnych ludzi i zawierać możliwe do spełnienia postulaty racjonalizatorskie. Miała to być krytyka najwyższej próby, ale - jak to bywa z drogocennymi kruszcami - niezmiernie rzadko występowała w naturze. Problem polegał na tym, że redakcja dopiero post factum dowiadywała się, czy proporcje w tekście były prawidłowe, a krytyka konstruktywna czy też - przeważnie - nie. O tym, czy kryteria zostały spełnione decydowała arbitralnie „góra”, niekiedy sami opisani na łamach z łatwym do przewidzenia rezultatem. Przykładowo, kontrowersje w Wydziale Prasy KC wzbudził numer wspomnianego już magazynu „Dookoła Świata”, ukazujący się w dziesięciolecie Polski Ludowej, ze względu na rzekomo szkodliwy politycznie obraz przedwojennej Rzeczypospolitej. „Materiał do tego numeru był szereg razy dyskutowany na kolegium, a mimo to u nikogo nie zrodziły się wątpliwości co

${ }^{56}$ AAN, KC PZPR, 237/VIII/362, Pisma w sprawie „tłumienia krytyki” w Koszalinie, k. 6-14; ibidem, Notatka w sprawie prasy z redakcjami (czerwiec 1954), k. 63-66.

${ }^{57}$ Referat przewodniczącego zarządu głównego SDP Henryka Korotyńskiego, „Prasa Polska” 1954, nr 5. 
do celowości ujęcia części pisma poświęconej przeszłości i przyszłości - stwierdził autor notatki. - Rozmowy te wykazały również, że mimo słownego uznania krytyki nie widzą oni w całej ostrości szkodliwości ww. pozycji i braku ostrości politycznej w opracowaniu całego materiału"58.

W przededniu kampanii propagandowej poprzedzającej wybory do rad narodowych w grudniu 1954 r. w KC krytycznie analizowano kampanię z 1952 r. Zachowana notatka $\mathrm{w}$ tej sprawie świadczy tyleż o rosnącej świadomości mankamentów dotychczasowego modelu propagandy, ile o braku wizji zmian ${ }^{59}$. Zresztą, ze względu na wstrząs, jaki wywołały audycje w Radiu Wolna Europa zbiegłego na Zachód byłego wicedyrektora X Departamentu Józefa Światty, który ujawniał tajemnice kompromitujące Bieruta i jego najbliższych współpracowników oraz odsłaniał zbrodnicze oblicze partii i aparatu terroru, co jesienią $1954 \mathrm{r}$. nadało odwilży w Polsce nowej dynamiki, w tym czasie raczej nikt nie zaprzątał sobie tym głowy.

Listopadowa narada tzw. centralnego aktywu partyjnego (uczestniczyło w niej kilku redaktorów naczelnych), która w zamyśle kierownictwa miała służyć poinformowaniu o rozwiązaniu X Departamentu MBP, zmianie kierownictwa aparatu bezpieczeństwa i zorientowaniu się w nastrojach, a przerodziła się w kilkudniową otwartą krytykę liderów - pierwsze złamanie dogmatu bezwzględnego podporządkowania decyzjom kierownictwa i zasady jednomyślności, odbiła się głośnym echem $\mathrm{w}$ partyjnym establishmencie ${ }^{60}$. Szybko pojawiła się potrzeba zorganizowania narady $\mathrm{z}$ dziennikarzami i przekazania prasie odpowiednich instrukcji. Spotkanie redaktorów prasy partyjnej z udziałem Ochaba i Bermana odbyło się niemal trzy tygodnie po naradzie aktywu, dopiero 21 grudnia 1954 r., już po opublikowaniu prasowego komunikatu o likwidacji/przekształceniu MBP. Była to zapewne pierwsza od czerwca 1953 r. okazja do spotkania dziennikarzy z przedstawicielami ścisłego kierownictwa partii.

W dużej mierze poświęcono je nastrojom panującym w warszawskich redakcjach i samo je odzwierciedlało: świadomość burzliwego przebiegu listopadowej narady centralnego aktywu niewątpliwie zachęciła dziennikarzy do większej odwagi. Trudno ocenić, czy zachowana notatka wiernie oddaje atmosferę spotkania, wydaje się, że w redakcji znacząco skrócono zapis i wygładzono ton wypowiedzi, analogicznie jak to miało miejsce w przypadku stenogramu z listopadowej narady centralnego aktywu ${ }^{61}$. Jeśli wierzyć notatce, w czasie całej narady Berman nie zabrał głosu ani razu, mówił tylko Ochab. Instruował dziennikarzy o sposobie pisania na temat sytuacji międzynarodowej i zadaniach w związku ze zbliżającymi

\footnotetext{
${ }^{58}$ AAN, KC PZPR, 237/VIII/362, Notatka, 5 VIII 1954 r., k. 77-78.

${ }^{59}$ AAN, KC PZPR, 237/VIII/362, Uwagi w sprawie kampanii wyborczej w prasie i radio - na podstawie doświadczeń z wyborów do sejmu, 6 X 1954 r., k. 95-99.

${ }^{60}$ Modzelewski - Werblan. Polska Ludowa. Rozmawia Robert Walenciak, Warszawa 2017, s. 91-93.

${ }^{61}$ A. Werblan, op. cit., s. 56.
} 
się wyborami do rad narodowych, pytał też o ocenę kontaktów redakcji z KC, poszczególnymi wydziałami i oczekiwania w tym zakresie. Na gorący temat rozwiązania MBP i nastrojów w redakcjach wypowiedział się dopiero w odpowiedzi na pytania z sali, zapewne chcąc wcześniej zorientować się w nastrojach.

Pretekstu do dyskusji dostarczył opublikowany w „Sztandarze Młodych” obok komunikatu o likwidacji MBP lakoniczny komentarz redakcji ${ }^{2}$. Dla jednych o krok za daleko, dla innych zbyt mały krok naprzód. „Znów mamy wiedzę dla siebie a nie dla czytelnika” - mówił Korotyński. Redaktor naczelna „Sztandaru" Irena Tarłowska broniła redakcji, wprost mówiła o zmieniających się dosłownie - z dnia na dzień wytycznych KC: „W sprawie komentarza - otrzymali poprzedniego dnia nastawienie, które na drugi dzień uległo zmianie. Dzieje się tak również i w mniej jaskrawych sprawach". Mówiąc o sytuacji całego środowiska, pytała: „Na naradzie reportażystów był niepokój - co można pisać, jakie są granice prawdy. Mógłby to być twórczy niepokój, gdyby ludziom troszkę więcej powiedzieć”. Inny uczestnik narady oceniał: „wszystkie artykuły w prasie w tej sprawie ocenia jako «międlenie». Zaczęliśmy już mówić z masami, a teraz mamy cofnięcie się wstecz. Kosztuje nas to znaczenie więcej niż dotychczas. Pracownicy radia i propagandy czują, że mają spętane ręce. Przyszedł czas, żeby zrewidować stanowisko w sprawie krytyki w radio i mówienia o trudnościach”. „Dlaczego prasa jest bezzębna? - pytał kolejny uczestnik dyskusji.

Dość otwarcie mówiono o pogardliwym stosunku aparatu partyjnego do dziennikarzy i - co za tym idzie - fatalnej współpracy z prasą, braku zainteresowania towarzyszy opiniami i nastrojami społecznymi. Jeden z mówców porównał przygotowywanie gazety rolniczej przy braku dostępu do informacji do „roboty cyrkowej”. Mówiono o ograniczeniach uniemożliwiających pisanie na temat ciężkich warunków życia, trudnej sytuacji rolnictwa. W odniesieniu do wychodzących na światło dzienne zbrodni aparatu bezpieczeństwa pojawił się nawet postulat poddania go pod kontrolę opinii publicznej, ktoś bowiem w odniesieniu do ówczesnej rzeczywistości trafnie zauważył, że wszystko jest regulowane, ale nie „jeśli idzie o prawa obywatela”.

Dziennikarze usłyszeli z ust Ochaba dość ogólnikową samokrytykę. W zasadniczej kwestii zbrodni aparatu bezpieczeństwa sekretarz KC przyznał, że problem nie ogranicza się do rozliczenia Stanisława Radkiewicza, ale chodzi o odpowiedzialność całego kierownictwa partyjnego. Zarazem zapowiedział, że w tej sprawie wypowie się plenum i do tego czasu „nie należy śpieszyć się z pytaniami”. Przyznawał, że dotychczasowe zmiany od czerwca 1953 r. miały charakter połowiczny i bez zmiany „stylu” kierownictwa nie zajdą dalej. Krytycznie ocenił wiarygodność informacji na łamach prasy, ale nie miał nic do powiedzenia jak pisać o złym zaopatrzeniu sklepów i sytuacji gospodarczej. Zgodził się z krytycznym

\footnotetext{
62 „Sztandar Młodych” 9 XII 1954 r.
} 
spojrzeniem na funkcjonowanie propagandowego aparatu KC, ale od razu zastrzegł, że jego roli nie należy przeceniać, bo nikt nie zdejmie odpowiedzialności z redakcji. „Aparat nie jest w stanie przejrzeć i dać analizę tego co prasa pisze" - stwierdzi163.

Zwołane kilka tygodni później, 21-24 stycznia 1955 r., III posiedzenie plenarne $\mathrm{KC}$, mimo głosów na temat rozliczenia odpowiedzialnych za "nadużycia” w aparacie bezpieczeństwa, nie miało temperatury listopadowej narady. Chcąc ograniczyć ferment wywołany wychodzącymi na światło dzienne faktami kompromitującymi aparat terroru i ścisłe kierownictwo partii, rządzący "triumwirat” zrzucał odpowiedzialność na wykonawców. Przywódcy PZPR po raz pierwszy ostrożnie przyznawali się do „błędów i wypaczeń”: deklarowali zmniejszenie znaczenia aparatu bezpieczeństwa i przywracanie (rzekomo istniejącej u zarania władzy „ludowej”) praworządności, stosowanie zasady kolegialności, zmianę stylu pracy aparatu partyjnego, prowadzenie bardziej realistycznej polityki gospodarczej ${ }^{64}$. Prasa zaczęła od razu pisać na temat plenum, choć opublikowano tylko referaty Bieruta i Morawskiego. „Z Sali obrad plenum pójdzie świeży powiew do całej partii, do wszystkich dziedzin życia - entuzjastycznie komentowała „Trybuna Ludu" w redakcyjnym artykule. - Swobodna i szczera dyskusja oraz głęboka partyjna krytyka odczuta była przez wszystkich uczestników plenum jako rzeczywiste zapoczątkowanie przełomu, który partii jest tak bardzo potrzebny"65.

Po raz pierwszy w dostępnych publicznie materiałach partyjnych przyznawano pośrednio, że dotychczas propaganda nie miała związku z rzeczywistością, który powinna odzyskać, by być bardziej skuteczna. Środkiem do celu była nie tyle korekta modelu zarządzania, co zmiana stylu, zmniejszenie stopnia zależności prasy od dyrektyw i bardzo szczegółowych instrukcji, do niedawna przesyłanych bez mała codziennie. Dziennikarze powinni być lepiej poinformowani, rzetelniej informować, odważniej polemizować $\mathrm{z}$ „wrogimi poglądami”, odsłaniać patologie administracyjne i społeczne. By rozluźnić pęta krępujące prasę, po raz pierwszy dopuszczono, przynajmniej formalnie, możliwość krytykowania działaczy partii wyższych szczebli, przede wszystkim w terenie.

W wyniku odwilżowych przetasowań personalnych w kierownictwie wzmocniła się pozycja Morawskiego, który zastąpił Ochaba i awansował na stanowisko sekretarza KC nadzorującego Wydziały Propagandy i Agitacji ${ }^{66}$, Nauki i Kultury oraz partyjne czasopisma „Trybunę Ludu” i „Życie Partii”. Jego nominacja

${ }^{63}$ AAN, KC PZPR, 237/VIII/361, Narada redaktorów z udziałem Ochaba i Bermana, 21 XII 1954 r., k. $1-11$.

${ }^{64}$ AAN, KC PZPR, III/12, Stenogram III plenarnego posiedzenia Komitetu Centralnego PZPR, 21-24 I $1955 \mathrm{r}$.

65 „Trybuna Ludu” 27 I 1955.

${ }^{66}$ Którym w dalszym ciągu kierował, doszło więc do „unii personalnej”: sekretarz KC Morawski formalnie nadzorował Morawskiego jako kierownika wydziału KC. 
wychodziła naprzeciw oczekiwanym przez Moskwę zmianom kadrowym, aby odsuwanych z ważnych funkcji towarzyszy żydowskiego pochodzenia zastępować towarzyszami pochodzenia polskiego, by zastępować starych młodszymi i - co nie bez znaczenia - mniej skompromitowanymi. W kwietniu $1955 \mathrm{r}$. funkcjonujące dotychczas odrębnie dwa wydziały Kultury i Nauki zostały połączone w jeden, na jego czele stanął Stefan Żółkiewski, wcześniej redaktor naczelny „Kuźnicy”, współodpowiedzialny za stalinizację kultury, obecnie zaliczany do zwolenników ostrożnej liberalizacji. W maju przedstawił aktualne stanowisko partii wobec dyskusji toczącej się wśród literatów: krytykował dogmatyzm i „wulgarne komenderowanie twórczością”, ale polemizował z „destrukcyjną krytyką" uprawianą według niego przez literatów: Jana Błońskiego, Mieczysława Jastruna, Artura Sandauera i Jerzego Andrzejewskiego ${ }^{67}$.

Wzmocnienie pozycji Morawskiego nie naruszało dotychczasowej nieformalnej hierarchii: jeszcze po XX zjeździe KPZR i śmierci Bieruta Berman bez konsultacji z autorem mógł zmienić fragment artykułu Morawskiego - było nie było sekretarza KC - na temat doświadczeń zjazdu w części odnoszącej się do oceny Gomułki i „odchylenia prawicowo-nacjonalistycznego"68. „I wie pani, jaka była moja pierwsza myśl? - wspominał Morawski w rozmowie z Teresą Torańską. - Że jeśli Berman to dopisał, to tak musi być. I te zdania przez niego wprowadzone muszą zostać. Bo ja z nim nie wygram. Berman miał ogromny autorytet, w starych kadrach kapepowskich nawet przesadny. I słowa «Jakub tak uważa», albo «Takie jest zdanie Jakuba», rozstrzygały dyskusję"69.

Morawski w programowym artykule na łamach „Nowych Dróg” przedstawił, jak należy odczytywać wytyczne III plenum KC, a w odniesieniu do literatury kurs na tych samych łamach wyznaczył Leon Kruczkowski ${ }^{70}$. Morawski wskazówki dla prasy zawarł w kilku zdaniach: „Dlatego propaganda mówić winna nie tylko o osiągnięciach, ale i o brakach, kłopotach i trudnościach, z jakimi się borykamy, traktować ludzi pracy tak, jak należy traktować gospodarzy kraju. [...] Szczególnie ważnym zadaniem $\mathrm{w}$ prasie, radio i w ustnej agitacji jest wydatne ulepszenie informacji politycznej i gospodarczej, informacji o najważniejszych interesujących społeczeństwo problemach i wydarzeniach w kraju, a także na arenie międzynarodowej. [...] Chcemy, aby ludzie śmielej wypowiadali nurtujące ich zastrzeżenia i wątpliwości po to, aby wątpliwości rozwiewać, zastrzeżenia przezwyciężać"71. Zwracał uwagę obszerny passus zapowiadający bezwzględną walkę z przypadkami „dławienia krytyki” lub ignorowania jej przez lokalny aparat partyjno-administracyjny, co mogło być odczytane przez dziennikarzy jako

\footnotetext{
${ }^{67}$ S. Żółkiewski, O aktualnych dyskusjach literackich, „Nowe Drogi” 1955, nr 6, s. 16-37.

${ }^{68}$ J. Morawski, Nauki XX Zjazdu, „Nowe Drogi” 1956, nr 3.

${ }^{69}$ Rozmowa z Jerzym Morawskim..., s. 167-169.

${ }^{70}$ L. Kruczkowski, Front kulturalny w świetle III Plenum, „Nowe Drogi” 1955, nr 3, s. 3-10.

${ }^{71}$ J. Morawski, III Plenum KC PZPR, „Nowe Drogi” 1955, nr 2, s. 15-17.
} 
zachęta do odważniejszego opisywania przypadków lokalnych patologii, a nawet nieśmiała sugestia, że mogą liczyć na wsparcie lub ochronę ze strony centrum. Wsparcie to - jak przekonali się z czasem - pozostało głównie werbalne.

Pod koniec lutego 1955 r. Biuro Polityczne stwierdziło, że prasa nie nadąża $\mathrm{z}$ realizacją uchwał III plenum. Mimo deklaratywnego uznania dla ukazujących się artykułów krytycznych zalecono, by „Trybuna Ludu” i cała prasa partyjna przestrzegały zasad „leninowskiej pryncypialności”. To słowo-wytrych w interpretacji kierownictwa służyło utemperowaniu prasy: walkę z „przejawami naruszania praworządności [...] bezduszności i biurokratyzmu" należało teraz pogodzić z unikaniem opisu zbyt konkretnych i niewygodnych dla władzy zjawisk - co w praktyce oznaczało mission impossible ${ }^{72}$. Politbiuro zaleciło organizowanie cyklicznych konferencji prasowych z udziałem przedstawicieli resortów gospodarczych. W praktyce wyglądało to tak, że wygłaszali oni komunikaty i nie odpowiadali na pytania $\mathrm{z}$ sali; dziennikarze nie mieli możliwości ich zadawania ${ }^{73}$.

Po posiedzeniu Politbiura ostateczne wnioski zredagowali Berman, Ochab i Morawski, po czym zostały rozesłane w teren. Zawarte w nich wytyczne skorygowania systemu zarządzaniu prasą przez komitety wojewódzkie i KC PZPR oraz wzajemnej współpracy zostały następnie omówione w czasie narady z udziałem sekretarzy propagandy KW i redaktorów naczelnych 8 marca 1955 r. ${ }^{74}$ Sporo miejsca poświecono analizie funkcjonowania Sektora Prasy $\mathrm{KC}^{75}$. Wnioski sprowadzały się do zamiaru dostarczania prasie bardziej wiarygodnych informacji, systematycznego analizowania i oceniania prasy, pomocy i ,inspiracji” w opracowaniu planów redakcyjnych, podjęcia rzeczywistej współpracy między KC, a komitetami wojewódzkimi w nadzorowaniu prasy, tej współpracy bowiem do tej pory nie było. O tych wnioskach warto wspomnieć wyłącznie dlatego, że dają wgląd w pomysły na zmodyfikowanie modelu zarządzania prasą. Świadczą o tym, że ludzie odpowiedzialni za propagandę partyjną mieli rosnącą świadomość wyczerpania dotychczasowej formuły. Zdawali sobie sprawę że - jeśli propaganda ma być skuteczna - potrzebne są w niej jakieś zmiany. Mieli o nich mgliste wyobrażenie i pozostali na poziomie ogólników; ze stwierdzeń o tym, że KC i KW powinny współpracować przy nadzorze prasy nic nie wynikało. Pomysły na zmiany $\mathrm{w}$ jakimś stopniu zrealizowano dopiero po przełomie politycznym

\footnotetext{
72 AAN, KC PZPR, V/30/, Protokół nr 32 posiedzenia BP, 24 II 1955 r., k. 22; ibidem, V/36, Problemy III plenum w prasie partyjnej, k. 33-35; ibidem, V/38, Wnioski w sprawie opracowywania przez prasę zagadnień III plenum, k. 146-150.

${ }^{73} \mathrm{~W}$ marcu Sekretariat KC polecił zorganizować konferencje na temat polityki rolnej - z Zenonem Nowakiem, przemysłu ciężkiego - z Piotrem Jaroszewiczem, wykonania budżetu - z Julianem Kole lub Tadeuszem Dietrichem. AAN, KC PZPR, V/30, Protokół nr 50 posiedzenia Sekretariatu KC, 22 III 1955 r., k. 165.

${ }^{74}$ AAN, KC PZPR, 237/VIII/361, Narada sekretarzy propagandy KW i redaktorów naczelnych prasy, 8 III 1955 r., k. 54-63. Stenogram narady: AAN, KC PZPR, 237/V/213.

${ }^{75}$ Komórka zajmująca się nadzorem nad prasą w ramach Wydziału Propagandy i Agitacji KC.
} 
w latach 1956-1957. Z dzisiejszej perspektywy może wręcz dziwić, jak można było poświęcić tak wiele czasu tak wielu mówców by zmienić tak niewiele.

Jedynym namacalnym skutkiem tych rozważań w kwietniu 1955 r. było uruchomienie przez Sektor Prasy biuletynu zawierającego uwagi o bieżącej sytuacji w redakcjach i wartych odnotowania artykułach, swoistego przeglądu prasy. Początkowo wydawano go dość regularnie, nawet cztery numery miesięcznie (w czerwcu), pod koniec roku częstotliwość zmalała do jednego - dwóch numerów miesięcznie. Przerwa w wydawaniu biuletynu między marcem a majem $1956 \mathrm{r}$. jest odzwierciedleniem wstrząsu spowodowanego przez XX zjazd KPZR. W kolejnych miesiącach biuletyn był wydawany nieregularnie ${ }^{76}$. W każdym razie w kierowaniu aparatem propagandowym posługiwano się wciąż tym samym martwym językiem, a stary model korygowano za pomocą starych metod: narad służących realizacji poleceń podejmowanych przez kierownictwo partii. W końcu, niezależnie od oficjalnych wytycznych, każdy dziennikarz, zwłaszcza ten pełniący funkcję w redakcji, i tak powinien mieć $\mathrm{z}$ tyłu głowy zasadę: „musimy dając materiał do druku zawsze się zastanowić komu on służy i czemu on służy i co z tego wyniknie" - jak z dialektyczną zręcznością i zaskakująco otwarcie sformułował to Korotyński ${ }^{77}$.

Z początkiem 1955 r. na łamach prasy kulturalnej zaczęly pojawiać się, początkowo nieśmiało, potem coraz śmielej, przemilczane wcześniej tematy społeczne. W „Przeglądzie Kulturalnym” Anna Pawełczyńska pisała o chuligaństwie, zakłamaniu i wulgarności, a Arnold Słucki o problemach młodzieży ${ }^{78}$. Aktualny temat szybko podjęli filmowcy w obrazie Uwaga, chuligani w reżyserii Jerzego Hoffmana i Edwarda Skórzewskiego, który otworzył tzw. czarną serię polskiego dokumentu. W „Nowej Kulturze” Leszek Kołakowski krytykował dogmatyzm marksistowskiej szkoły filozoficznej. W kwietniu nakładem PWN ukazała się, w rok po premierze w ZSRR, głośna powieść Ilii Erenburga Odwilż, od której tytułu zaczęto nazywać zachodzące w bloku zmiany ${ }^{79}$.

Na rezultaty zachęt do większej śmiałości nie trzeba było długo czekać, w ciągu pierwszych dwóch miesięcy 1955 r. na łamach prasy zaczęła rosnąć liczba publikacji krytycznych i interwencyjnych, co szybko przełożyło się na liczbę starć gazet $z$ lokalnym i centralnym aparatem partyjnym i państwowym. Sprzeczność między deklarowanym przez władze prawem do krytyki a obawą przed osłabieniem dyscypliny siała ferment. Nawet jednostkowe sprawy docierały na najwyższy

\footnotetext{
${ }^{76}$ Analiza własna. Po biuletynie nr 23 z datą 8 marca 1956 r. kolejny biuletyn (z zachowaną numeracją) nosi datę 12 maja $1956 \mathrm{r}$.

77 AAN, KC PZPR, 237/V/213, Stenogram narady sekretarzy propagandy KW i redaktorów naczelnych prasy, 8 III 1955 r., k. 121.

78 A. Pawełczyńska, O kłamstwie, zakłamaniu, wulgaryzacji i chuligaństwie, „Przegląd Kulturalny” 1955, nr 1; A. Słucki, Trudne sprawy pokolenia, „Przegląd Kulturalny” 1955, nr 3, s. 2; T. Mielczarek, Od „Nowej Kultury” do „Polityki”..., s. 151-153; idem, Liberałowie i rewizjoniści..., s. 104.

${ }^{79}$ I. Erenburg, Odwilż, tłum. J. Brzechwa, Warszawa 1955.
} 
szczebel i powodowały ożywioną wymianę korespondencji. Przykładowo artykuł Prefabrykowane partactwo opublikowany 2 lutego 1955 r. w „Życiu Warszawy” oburzył ówczesnego kierownika Wydziału Przemysłu Ciężkiego KC Edwarda Gierka. Uruchomił on łańcuszek korespondencji z wyjaśnieniami między ówczesnym wicepremierem Stefanem Jędrychowskim, a ministrem i wiceministrem budownictwa przemysłowego oraz ich podwładnymi z zespołu „Miastoprojekt Kraków"80. W maju Sekretariat KC powołał komisję z udziałem przedstawicieli kilku wydziałów KC i „Trybuny Ludu” do zbadania opisanej w artykule sytuacji w porcie w Gdańsku ${ }^{81}$.

Narady, odprawy, szkolenia przedstawicieli lokalnego aparatu władzy były coraz częściej forum przekazywania kierownictwu pretensji pod adresem prasy. W czasie szkolenia 28 kwietnia 1955 r. kierownicy wydziałów propagandy komitetów powiatowych PZPR skarżyli się na zamieszczanie krytyki „,niedostatecznie sprawdzonej", niepublikowanie sprostowań i ton rozmowy z dziennikarzami prasy centralnej, mający rzekomo charakter przesłuchan. Z żalów wylewanych przez towarzyszy z terenu wyłania się sugestywny obraz popłochu, w jaki byli wprawiani przez dziennikarzy, w szczególności z Warszawy. Na przykład w Mysłowicach na wieść o przyjeździe przedstawiciela prasy centralnej „ «wybucha panika» i ludzie uciekają w teren" $"$. Zbyt liberalny stosunek redakcji do rzekomo nierzetelnych artykułów krytycznych był już stałym motywem ocen prasy partyjnej dokonywanej przez egzekutywy komitetów wojewódzkich ${ }^{83}$. Z kolei narady i szkolenia z przedstawicielami lokalnej prasy były coraz częściej zdominowane przez narzekania dziennikarzy na konflikty $z$ organizacjami partyjnymi i aparatem administracyjnym ${ }^{84}$.

Brak jasności, co jest dozwolone, a co nie, oznaczał, że rosła presja na centrum, coraz częściej zmuszone do gaszenia pożarów. Już 1 marca Sekretariat KC omawiał dwa artykuły o „błędnym wydźwięku ideologicznym” opublikowane na łamach „Trybuny Ludu” i „Przeglądu Kulturalnego" ${ }^{55}$. Już sam tytuł tekstu Jadwigi Siekierskiej, zasłużonej partyjnej teoretyczki i krytyczki sztuki, kwestionował dotychczas wyłączną prerogatywę partii: O sztuce decydować winni ludzie $s z t u k i{ }^{86}$. Autorka, która wojnę spędziła w łagrach w obwodzie riazańskim i pod Archangielskiem, a po $1945 \mathrm{r}$. z racji pełnionych funkcji nadzorowała różne sfery

\footnotetext{
${ }^{80}$ AAN, KC PZPR, V/36, Uwagi dot. artykułu w „Życiu Warszawy” prefabrykowane partactwo, k. 5-12.

${ }^{81}$ AAN, KC PZPR, V/30, Protokół nr 58 posiedzenia Sekretariatu KC, 31 V 1955 r., k. 198.

${ }^{82}$ AAN, KC PZPR, 237/VIII/363, Biuletyn nr 4 Sektora Prasy, 30 IV 1955 r., k. 36-37.

${ }^{83}$ Np. AAN, KC PZPR, 237/VIII/363, Biuletyn nr 9 Sektora Prasy, 13 VI 1955 r., k. 86-88.

${ }^{84}$ Np. AAN, KC PZPR, 237/VIII/363, Biuletyn nr 8 Sektora Prasy, 4 VI 1955 r., k. 71-72; E. Grygo, Prasa partyjna wobec wydarzeń w 1956 roku, „Kwartalnik Historii Prasy Polskiej” 1985, nr 1, s. $115-116$.

${ }^{85}$ AAN, KC PZPR V/30, Protokół nr 47 posiedzenia Sekretariatu KC, 1 III 1955, k. 152-153.

${ }^{86}$ J. Siekierska, O sztuce winni decydować ludzie sztuki..., „Przegląd Kulturalny” 1955, nr 8, s. 2.
} 
życia kulturalnego, w okresie odwilży po 1953 r. wyraźnie przewartościowała część poglądów. W czasie 11. sesji Rady Kultury i Sztuki w 1954 r. opowiedziała się po stronie twórców starających się rozluźnić gorset partyjnego nadzoru nad kulturą ${ }^{87}$. Jej artykuł był znaczącym manifestem w tej sprawie. Spotkał się z odporem na łamach „Trybuny Ludu”88, ale otworzył trwającą kilka miesięcy dyskusję, której nie zamknęła próba podsumowania podjęta przez Stefana Żółkiewskiego ${ }^{89}$. Na przełomie marca i kwietnia Politbiuro poddało krytyce redakcję „Szpilek”, uznając, że zamieszczane na łamach materiały świadczą „,nie tylko o zamęcie ideologicznym, ale mają również charakter wypadów antypartyjnych świadczących o naporze wrogiej ideologii”. Redaktor naczelny „Szpilek” Zbigniew Mitzner zapłacił swoim stanowiskiem (zastąpił go Arnold Mostowicz), a jego zastępca naganą partyjną ${ }^{90}$. Do maja Sekretariat KC zdecydował o zmianie redaktor naczelnego „Gazety Poznańskiej”, „Głosu Szczecińskiego”, „Gazety Krakowskiej”, tygodnika „Przyjaźń”91.

Biuro Politycznie ponownie zajmowało się prasą już 18 marca 1955 r. Brzmienie tego punktu porząaku obrad: „zabezpieczenie kierownictwa politycznego w dziedzinie prasy i wydawnictw" sugeruje, że owo kierownictwo postrzegano już w centrum jako niepewne. Odpowiedzią miała być ponowna (re)interpretacja postanowień III plenum - czyli naciśnięcie na hamulec. Zajęła się tym komisja (Berman, Morawski, Zambrowski, Walenty Titkow), która przygotowała projekt uchwały KC w sprawie realizacji uchwał III plenum. Nadano jej formę listu do komitetów wojewódzkich i powiatowych PZPR, zatwierdzonego przez Politbiuro na początku kwietnia ${ }^{92}$. Został on omówiony 2 kwietnia w czasie narady Warszawskiego Oddziału SDP z udziałem kilkuset osób. Największy wpływ na treść listu miał Berman, ale - jak już w literaturze zauważono - dokument był niespójny, dawał możliwość dowolnej interpretacji ${ }^{93}$. To mogło być odzwierciedleniem rozbieżności narastających w centrum władzy.

Biuro Polityczne krytykowało organizacje, które nie prowadzą ostrej walki $\mathrm{z}$,faktami dławienia krytyki, zastraszania, komenderowania. [...] Nie wyciąga się

${ }^{87}$ Biogram Jadwigi Siekierskiej: http://www.ipsb.nina.gov.pl/a/biografia/jadwiga-siekierska (dostęp: 22 V 2018).

${ }^{88}$ A. Weber, Stuszne intencje i fałszywe wnioski, „Trybuna Ludu” 1955, nr 71.

${ }^{89} \mathrm{~J}$. Ćwiertnia, O smaku destylowanej wody, o metodzie uchylania drzwi i jeszcze o kilku sprawach natury artystycznej, „Przegląd Kulturalny” 11, s. 8; J. Putrament, Przeciwko sztuce abstrakcyjnej, ibidem, nr 13, s. 2; Z. Polsakiewicz, O realistycznej i antyrealistycznej deformacji, o tym, czego nie należy wpuścić przez otwarte drzwi i jeszcze o kilku sprawach natury politycznej, ibidem, nr 13, s. 4; R. Zimand, Uwagi o deformacji i realizmie, ibidem, nr 14, s. 4; J. Putrament, O socjalistyczna krytykę literacka, ibidem, nr 24, s. 1-2; S. Żółkiewski, Czy dyskusja o sztuce jest dyskusją polityczną, ibidem, nr 27, s. 6; J. Przyboś, Wnioski i propozycje, ibidem, nr 43, s. 3.

${ }^{90}$ AAN, KC PZPR V/30, Protokoły 38, 39 posiedzeń BP, 28 i 31 III, 1 IV 1955 r., k. 39.

${ }^{91}$ AAN, KC PZPR V/30, Protokół nr 58 posiedzenia BP, 31 V 1955 r., k. 195-199.

92 AAN, KC PZPR, V/30, Protokół nr 40 posiedzenia BP, 8 IV 1955 r., k. 42-43.

${ }^{93}$ A. Kozieł, Studium o polityce prasowej..., s. 108-109. 
też stanowczych wniosków wobec tłumicieli krytyki, kumoterskich klik «kacyków» i bezideowych elementów. [...] Fakty te nie są też w dostatecznej mierze oświetlane przez prasę". Kilka akapitów dalej Politbiuro informowało o chwiejności i zamęcie ideowym w środowiskach literackich i dziennikarskich, pozbawionych „partyjnej pryncypialności w krytyce” i ulegających "naciskowi drobnomieszczaństwa”. W tym kontekście wymieniono wspomniane powyżej artykuły w "Szpilkach”, „Przeglądzie Kulturalnym” i „Nowej Kulturze”, czemu - jak zauważano - nie przeciwstawiała się prasa partyjna ${ }^{94}$. O ile tzw. pisma literackie stanowiły odrębny przypadek - o czym za chwilę - o tyle casus „Szpilek” jest świetnym przykładem ślepej ulicy, w której znaleźli się przywódcy partii ze swoją polityką prasową. Tygodnik bowiem próbował ją realizować, z sukcesami zwiększając atrakcyjność pisma. Doszło do tego, że, jak donoszono np. z Oleśnicy, sprzedawcom polecono, by sprzedawali „Szpilki” lub „Przekrój” tylko z dodatkiem zalegającej „Trybuny Ludu” i „Gazety Robotniczej” 95 .

Efektem listu było słabnięcie krytyki na łamach prasy i falach radia, odnotowywane od kwietnia 1955 r. w Wydziale Prasy KC. „ «Życie Warszawy» może służyć do pewnego stopnia jako przykład zjawiska osłabienia krytyki i śmiałości oraz odejścia od trudnych tematów, jakie widzimy w całej prasie. Tym bardziej to uderza, że «Życie» było tradycyjnie pismem wyróżniającym się śmiałością i samodzielnością" - stwierdzano $\mathrm{w}$ przeglądzie prasy ${ }^{96}$. W jeszcze większym stopniu dotyczyło to prasy regionalnej. Bezpośrednio po III posiedzeniu plenarnym KC do „Trybuny Robotniczej” zgłaszali się górnicy, którzy, powołując się na uchwały plenum, mówili o fatalnych warunkach pracy; z biegiem czasu było ich coraz mniej. Szybko spadała liczba listów do „Trybuny Robotniczej”, w okresie od 1 do 15 maja spadła do 606, w porównaniu z 779 (w okresie 1-15 kwietnia) i 1079 w pierwszej połowie marca. Autorzy listów coraz rzadziej pisali o sytuacji we własnym zakładzie pracy, „,o jest wynikiem coraz bardziej wyrafinowanych i dość powszechnie stosowanych metod tłumienia krytyki”. Należały do nich drobiazgowe sprawdzanie prawdziwości zarzutów lub naciski, by „krytyka” wyżywała się raczej na łamach gazet zakładowych i radiowęzłów kontrolowanych przez lokalne władze, a nie pism ogólnopolskich - co narażało lokalny aparat na nieprzyjemność tłumaczenia się przed „górą". W rezultacie trzeźwo stwierdzano narastający rozziew pomiędzy tym, co można było znaleźć na łamach prasy, a potrzebami i oczekiwaniami czytelników. Rozziew, który - co trzeba podkreślić - pozostawał ogromny ${ }^{97}$.

W notatce z maja $1955 \mathrm{r}$. na podstawie relacji z narad w poszczególnych redakcjach ponownie położono nacisk na wrogi stosunek aparatu wojewódzkiego

\footnotetext{
94 AAN, KC PZPR, V/31, List Komitetu Centralnego do KW i KP, kwiecień 1955 r.

95 AAN, KC PZPR, 237/XXV/13, Biuletyn Biura Listów i Inspekcji, 14 III 1955 r., k. 124.

${ }^{96}$ AAN, KC PZPR, 237/VIII/363, Biuletyn nr 4 Sektora Prasy, 30 IV 1955 r., k. 32.

97 AAN, KC PZPR, 237/VIII/363, Biuletyn nr 6 i 9 Sektora Prasy, 21 V, 13 VI 1955 r., k. 52, 81.
} 
do prasy i artykułów krytycznych. Jak to wyglądało w praktyce, zilustrowano przykładem skargi złożonej przez aktora, który poczuł się dotknięty krytyczną recenzją i - zamiast napisać do gazety - zwrócił się do Wojewódzkiej Komisji Kontroli Partyjnej. Wyjaśnianie sprawy komisja rozpoczęła od wizyty w redakcji i... zapoznania się z ankietą personalną autorki krytycznego tekstu, z czego zrezygnowano dopiero po interwencji z Warszawy. Mimo to autorka została wezwana na przesłuchanie do KW, gdzie nakłaniano ją do podpisania oświadczenia odwołującego zarzuty. Reasumując opinie wyrażone przez dziennikarzy, podkreślano dużą bezsilność redakcji w „egzekwowaniu krytyki, powszechne ukrywanie braków przed prasą, brak poparcia w aparacie partyjnym i wręcz gorszą atmosferę do krytyki niż kiedykolwiek". Jedyne rozwiązanie problemu widziano w - jakże by inaczej - wspólnej naradzie I sekretarzy KW z redaktorami naczelnymi z udziałem przedstawicieli kierownictwa. Nawet do tego spotkania najprawdopodobniej nie doszło ${ }^{98}$.

Wiosną 1955 r. Oddział Cenzury Wojskowej Sztabu Generalnego przygotował projekt nowego, ostrzejszego zarządzenia prezesa Rady Ministrów w sprawie kontroli prasy. Przypuszczalnie był on rezultatem poczucia zagrożenia utraty kontroli nad prasą i próbą założenia jej kagańca. Przeciwko projektowi protestowali wspólnie szef cenzury cywilnej Marian Mikołajczyk i redaktor naczelny „Trybuny Ludu” Roman Werfel. We wspólnym liście do kierownictwa partii twierdzili, że jeśli chodzi o zakres dopuszczalnych informacji o życiu gospodarczym i społecznym kraju towarzysze z cenzury wojskowej „skłonni są traktować jako tajemnicę wojskową spraw powszechnie znanych, których opublikowanie nie może w istocie narazić na szkodę interesów państwowych, a zatrzymywanie niepotrzebnie hamuje prace gazet”. Zgodnie oceniali projekt jako „zbyt rozciągliwy” i niedający prasie, a nawet Głównemu Urzędowi Kontroli możliwości odwołania się od decyzji ${ }^{99}$. Projekt nie wszedł w życie. Jedyne informacje o nim czerpiemy ze wspomnianego listu Mikołajczyka i Werfla. Jaka była rola Konstantego Rokossowskiego? Czy w centrum władzy poważnie rozważano wprowadzenie zarządzania zaostrzającego cenzurę?

W związku z odnotowywanym „osłabieniem krytyki prasowej” 2 maja w siedzibie SDP odbyła się narada kierowników redakcji warszawskich z udziałem Morawskiego. W jej trakcie wybrzmiało wreszcie głośno to, co myślało już wielu dziennikarzy: „słyszy się często - i to jest szczególnie jaskrawym wyrazem tej dezorientacji - że nie wiedzą czego partia chce"; głośno mówiono o odrodzeniu „wewnętrznego cenzora”. Zebranie było poświęcone wyjaśnieniu wątpliwości co do oczekiwań partii i istoty prowadzonej przez nią "walki na dwa fronty”.

${ }^{98}$ AAN, KC PZPR, V/36, Notatka w sprawie przebiegu niektórych narad w redakcjach, 25 V 1955 r., k. 132-134.

${ }^{99}$ AAN, KC PZPR, V/36, List prezesa GUKPPiW Mariana Mikołajczyka i redaktora naczelnego „Trybuny Ludu” Romana Werfla do Sekretariatu KC PZPR, 1 VI 1955 r., k. 135. 
Osoba, która wymyśliła to określenie polityki partii, najwyraźniej nie miała na względzie historycznego doświadczenia, uczącego, że walka na dwa fronty kończy się klęską. Wszak z dzisiejszej perspektywy jest jasne, że była to próba godzenia ognia $\mathrm{z}$ wodą. Ujawnienie nawet skromnej części patologii aparatu partyjnego i administracyjnego nazywane „walką przeciw komenderowaniu i tłumieniu krytyki” musiało spotkać się z jego oporem maskowanym hasłami o „osłabieniu dyscypliny” i „pomniejszaniu kierowniczej roli partii”. Nawet anonimowi autorzy notatki sceptycznie oceniali rezultaty spotkania redaktorów naczelnych z Morawskim i narad w redakcjach ${ }^{100}$.

Tak też było w istocie. Gdy po zebraniu z Morawskim zorganizowano spotkanie redakcji „Życia Warszawy”, w czasie dyskusji dominowały głosy „o dezorientacji w sprawach kultury, asekuranctwie, wyczekiwaniu, a nawet zniechęceniu do poruszania trudniejszych tematów". Redaktor naczelny, Korotyński, w ekwilibrystyczny sposób łączył apel o powrót do „żywej działalności” z ostrzeżeniem przed powtarzaniem „błędów i wypaczeń" nadmiernej krytyki ${ }^{101}$. Podobne były nastroje w redakcji warszawskiego „Expressu Wieczornego”, popularnej warszawskiej popołudniówki. Znaczna część zespołu oceniała, że kierownictwo redakcji „gubi się w szczegółach, zamienia się w cenzorów i korektorów, nie wysuwa koncepcji, nie omawia i nie ocenia politycznie ani gazety, ani materiałów. Towarzysze ci boją się krytycznych pozycji” - oceniano, zauważając, że wielu zmęczonych sytuacją członków redakcji myśli o odejściu z pracy ${ }^{102}$. Obawy potęgowały w środowisku dziennikarskim informacje o przebiegu plenarnego posiedzenia zarządu głównego Związku Literatów Polskich 10-11 czerwca 1955 r., w czasie którego Putrament wygłosił konsultowany na najwyższym szczeblu referat na temat realizacji zaleceń III plenum. Mówił w nim m.in. o recydywie burżuazyjnego pojmowania sztuki ${ }^{103}$. Literaci, intelektualiści i dziennikarze nie byli co prawda przez władze traktowani tak samo, ale atmosfera sprzyjała komentowaniu informacji, przemów i decyzji formalnie adresowanych do innych środowisk. Zbliżeniu sprzyjało poczucie jazdy na jednym wózku: obawa, że jeśli będzie przykręcana śruba - to wszystkim.

Z perspektywy czasu Jerzy Morawski określił politykę kierownictwa PZPR mianem „zygzakowatej linii”. W istocie jej cel sprowadzał się do zachowania kontroli nad sytuacją. ",To nie mogło się udać” - realistycznie oceniał po latach ${ }^{104}$. Często można spotkać się ze stwierdzeniem, że okresy liberalizacji przeplatały się z momentami przykręcania śruby, co jest opisem obrazowym, ale raczej nieoddającym istoty rzeczy. Bliżej prawdy wydaje się obraz chaosu, w którym w różnych sferach pojawiały się niemal równocześnie sprzeczne sygnały, wychwytywane

\footnotetext{
100 AAN, KC PZPR, 237/VIII/363, Biuletyn nr 5 i 6 Sektora Prasy, 9, 21 V 1955 r., k. 39-41; 49-52.

101 AAN, KC PZPR, 237/VIII/363, Biuletyn nr 5 i 6 Sektora Prasy, 9 V 1955 r., k. 40-41.

102 AAN, KC PZPR, 237/VIII/363, Biuletyn nr 7 Sektora Prasy, 30 V 1955 r., k. 59-60.

103 T. Chrząstek, op. cit., s. 190-191.

${ }^{104}$ Rozmowa z Jerzym Morawskim..., s. 154.
} 
i komentowane na bieżąco, co dodatkowo podgrzewało atmosferę. Impulsy z centrum wprowadzały zamęt, w którym trudno było się odnaleźć. Partia wymagała niemożliwego i chaotycznie, ale już nie bezwzględnie, karała. „Wszystko stało się niejednoznaczne, nieproste - powstał straszny bałagan" - Zbysław Rykowski i Wiesław Władyka obrazowo opisywali narastający ferment i przemiany świadomości przyspieszające $\mathrm{w}$ drugiej połowie $1955 \mathrm{rr}^{105}$

W końcu czerwca 1955 r. w KC dokonano swego rodzaju bilansu kadr w prasie i systemie zarządzania propagandą, funkcjonującym bez większych zmian od 1950 r. Świadczy to o narastającej krytycznej ocenie dotychczasowego modelu. $\mathrm{Z}$ dzisiejszej perspektywy pozwala na wyrobienie opinii na temat jego (nie)wydolności i zarazem (nie)realności wyzwania, jakim było odejście od głęboko zakorzenionego wzorca - ręcznego sterowania propagandą. Autorzy notatki poprzestali na opisie i - poza ogólnikami - nie formułowali żadnych wniosków. Brak refleksji na temat modyfikacji sposobu zarządzania prasą za pomocą narad i odpraw dowodzi, że z perspektywy centrum model prasy jako ramienia polityki partii pozostawał oczywistością.

Jak wynika z bilansu, podstawowy model działania Sektora Prasy polegał na organizowaniu narad redaktorów naczelnych, dziennikarzy centralnej i regionalnej prasy partyjnej i tzw. czytelnikowskiej, w czasie których omawiano bieżące zadania propagandowe. Drugim elementem tego modelu były cykliczne oceny pracy redakcji, dokonywane $\mathrm{w}$ oparciu o opracowania sporządzone na podstawie analizy zawartości czasopisma za dany okres. Tymczasem w całym Wydziale Prasy pracowało wówczas 11 osób, do których obowiązków należało nadzorowanie pracy redakcji 40 dzienników, redakcji Polskiego Radia w Warszawie, 8 rozgłośni wojewódzkich i 9 ekspozytur, około 20 tygodników i innych czasopism, Polskiej Agencji Prasowej, Agencji Robotniczej, Centralnej Agencji Fotograficznej, Robotniczej Spółdzielni Wydawniczej „Prasa”, Państwowego Przedsiębiorstwa Kolportażu „Ruch”, Głównego Urzędu Kontroli Prasy, Publikacji i Widowisk oraz $\mathrm{SDP}^{106}$. W praktyce oznaczało to, że wśród pracowników było kilku takich, którzy musieli zajmować się jednocześnie nawet dziewięcioma redakcjami. Samokrytycznie oceniano, że w tej sytuacji wydział był w stanie systematycznie kontrolować wyłącznie niektóre redakcje prasy centralnej i wojewódzkiej prasy partyjnej;

${ }^{105}$ Z. Rykowski, W. Władyka, op. cit., s. 93-105.

106 Wydział sprawował nadzór nad całą polską prasą i instytucjami z nią związanymi: GUKPPiW, RSW „Prasa”, PPK „Ruch”, SDP. Kontrolował pracę redakcji dzienników partyjnych (poza „Trybuną Ludu"), dzienników porannych, popołudniowych, czasopism społecznych i kulturalnych (poza „Nowymi Drogami” i „Życiem Partii”), prasą, kobiecą, magazynami, wydawnictwami dla zagranicy, PAP, Agencją Robotniczą, Agencją Publicystyczno-Informacyjną, Zachodnią Agencją Prasową (zlikwidowaną w 1948 r. i reaktywowaną w grudniu 1956 r.), Centralną Agencją Fotograficzną, Komitetem ds. Radia i Telewizji, Polską Kroniką Filmową. Pośrednio kontrolował prasę związkową, młodzieżową i wojskową, stronnictw ZSL i SD i tzw. postępowych katolików. E. Grygo, Z problematyki kierownictwa prasa PZPR..., s. 71-72, 77-78. 
a nadzór nad cenzurą, „Ruchem” czy SDP miał charakter incydentalny. W praktyce przedstawiciele wydziału KC kontaktowali się wyłącznie z szefostwem redakcji i nie znali sytuacji wewnątrz poszczególnych zespołów. Ponieważ nie znamy nazwisk pracowników Wydziału Prasy KC, nie wiemy, jaki był charakter ich relacji z formalnie nadzorowanymi instytucjami i stojącymi na ich czele ludźmi: komu wydawali polecenia, a kto miał na tyle mocną pozycję, długi staż partyjny i znajomości na najwyższym szczeblu, że musiał być traktowany jak partner - tak jak redakcja „Trybuny Ludu”. Jaki był status ludzi z trzeciego szeregu: kierującego cenzurą Mariana Mikołajczyka i Lucjusza Domańskiego - szefa Polskiej Agencji Prasowej? W centrum dostrzegano braki kompetencji i wyrobienia ideologicznego szeregowych pracowników mających nadzorować wyspecjalizowanych dziennikarzy. „W bardziej skomplikowanych sytuacjach politycznych występują zjawiska dezorientacji a nawet wahnięcia" - stwierdzano. Konferencje w KC z udziałem przedstawicieli ministerstw odbywały się co dwa tygodnie, ale ich jakość pozostawiała wiele do życzenia.

Jeśli chodzi o ocenę sytuacji w redakcjach warszawskich czasopism i w Polskim Radiu, z punktu widzenia władz dotkliwie brakowało ludzi na stanowiskach kierowniczych, m.in. w Agencji Robotniczej, wielu redakcjach Polskiego Radia, „Expressie Wieczornym”, „Chłopskiej Drodze”, „Trybunie Wolności”, zastępców redaktorów naczelnych w „Sztandarze Młodych” i „Życiu Warszawy”, w którym krytycznie oceniano kierownictwo działów ekonomicznego i kulturalnego. Równie źle oceniano sytuację w tzw. prasie młodzieżowej, w której z jednej strony brakowało dziennikarzy zdolnych, znających się na problemach, o których pisali, a z drugiej postulowano pozbycie się tych, „którzy zdążyli się już zaśniedzieć w prasie młodzieżowej, przejawiają lekceważący stosunek do aparatu ZMP, powodują w wielu wypadkach niezdrowy ferment w zespołach". W ocenie wydziału, ZMP w zasadzie nie nadzorował teoretycznie podległych mu dziennikarzy. Odnotowano wreszcie, będące zwiastunem nadchodzących wydarzeń, przypadki podważania roli redaktora naczelnego, w czym widziano niebezpieczeństwo „fałszywego pojmowania kolegialności".

Odnotowano także duże problemy z obsadą kierowniczych stanowisk w terenie: brakowało redaktorów naczelnych „Trybuny Mazowieckiej” i „Głosu Koszalińskiego", w dziesięciu lokalnych gazetach brakowało zastępców naczelnych, a w dwóch nawet sekretarzy redakcji. O ile wysoko oceniano zespoły redakcyjne w Stalinogrodzie (Katowicach), Krakowie, Wrocławiu, Kielcach i Gdańsku, o tyle za „bardzo słabe, szare i bezbarwne” uważano redakcje w Zielonej Górze, Koszalinie i Białymstoku. Zwracano wreszcie uwagę na trudne warunki lokalowe, $\mathrm{w}$ jakich funkcjonowało wiele redakcji w stolicy i terenie oraz ciężkie warunki życia wielu dziennikarzy - tu padł przykład dziennikarza mieszkającego z żoną i dzieckiem w dawnej oborze PGR oraz redakcji „Życia Warszawy”, w której ciężko chorowało 12 osób, w tym osiem na gruźlicę. Biorąc pod uwagę plany 
tworzenia nowych gazet $\mathrm{w}$ miastach wojewódzkich, nowych popołudniówek, magazynów i czasopism ilustrowanych, postulowano zwiększenie wydolności systemu kształcenia dziennikarzy ${ }^{107}$.

Zwróćmy uwagę na strukturalny problem machiny propagandowej, który okazał się mieć zasadnicze znaczenie w 1956 r.: brak rozgraniczenia kompetencji w zakresie kierowania i nadzorowania redakcji prasy partyjnej szczebla wojewódzkiego między $\mathrm{KC}$ a komitetami wojewódzkimi, którym formalnie podlegały organizacyjnie i personalnie (były w ich nomenklaturze). Wydział Prasy KC często przekazywał redakcjom bezpośrednie polecenia z pominięciem komitetów wojewódzkich, które w tej sytuacji oddawały pole centrali. Zarazem, realistycznie oceniano w wydziale, centrum nie było w stanie ręcznie sterować ani nadzorować pracy wszystkich redakcji wojewódzkiej prasy partyjnej, zwłaszcza na peryferiach. Na przykład w Zielonej Górze przedstawiciela wydziału nie widziano od siedmiu miesięcy, a jeden z redaktorów „Gazety Olsztyńskiej” już w 1956 r. żalił się, że KC pozostawił gazetę samą sobie co najmniej od półtora roku. To zaś oznaczało pełne uzależnienie peryferyjnych redakcji od lokalnych komitetów wojewódzkich PZPR, w praktyce zaś pierwszych sekretarzy KW. Gdy w 1956 i 1957 r. redakcje kilku wojewódzkich dzienników partyjnych znalazły się w otwartym konflikcie z miejscowymi komitetami wojewódzkimi, podjęte przez nie próby poszukiwania wsparcia centrum były z góry skazane na niepowodzenie.

Latem 1955 r. praca nadzorców „frontu propagandowego” biegła jak zawsze rytmem wyznaczanym przez kolejne plena, narady, odprawy, wydarzenia wymagające programowania przekazu, a następnie oceny realizacji tych zaleceń na łamach prasy. Pod koniec lipca miała miejsce narada poświęcona omówieniu IV posiedzenia plenarnego KC. Już z pewnej perspektywy oceniono, że rola prasy centralnej z "Trybuną Ludu” na czele w „rozkołysaniu dyskusji” na jego temat była żadna. Światowy Festiwal Młodzieży i Studentów w Warszawie był dla pracowników Sektora Prasy okazją do zorganizowania serii kilkuosobowych spotkań z redaktorami naczelnymi. Oprócz głównego tematu, niskiej wiarygodności publicystyki międzynarodowej i - już tradycyjnie - kwestii „krytyki”, pojawiły się nowe wątki świadczące o narastającej frustracji dziennikarzy, wynikającej z ograniczeń uniemożliwiających pisanie o tematach ważnych dla czytelników. Niemal wszyscy w poczuciu bezradności mówili, że otrzymują dużo listów w sprawie braków chleba, poruszono też wątek niszczenia wsi i miasteczek na Ziemiach Zachodnich jako konsekwencji forsownej industrializacji. W KC systematycznie analizowano publicystykę poświęconą festiwalowi młodzieży oraz międzynarodowej konferencji w Genewie w dniach 18-23 lipca, odbywającej się w klimacie wyraźnego ocieplenia stosunków między Wschodem a Zachodem ${ }^{108}$.

107 AAN, KC PZPR, 237/VIII/363, Biuletyn Sektora Prasy nr 11, 29 VI 1955 r., k. 98-110.

108 AAN, KC PZPR, 237/VIII/363, Biuletyny Sektora Prasy nr 14 i 15, 13 VIII i 9 X 1955 r., k. 134-151. 
Wkrótce po zakończeniu festiwalu młodzieży burzę w partyjnych i redakcyjnych gabinetach, kawiarniach i na łamach prasy wywołał Poemat dla dorostych Adama Ważyka, opublikowany przez „Nową Kulturę” 21 sierpnia 1955 r. ${ }^{109}$ Autor, który kilka lat wcześniej był jednym z najważniejszych, najbardziej zaangażowanych i agresywnych piewców stalinizmu, dokonał z nim ostentacyjnego rozrachunku. Zniszczył fundament: stalinowski mit Nowej Huty - rzekome ucieleśnienie marzeń o nowym, idealnym mieście, zakładzie przemysłowym i awansie społecznym klasy robotniczej. Ukazał obłudę propagandy, fałsz socrealizmu i demoralizację chłoporobotników wyrwanych z tradycyjnych wiejskich społeczności.

Trwała jeszcze otwarta w czasie festiwalu w warszawskim Arsenale Ogólnopolska Wystawa Młodej Plastyki, z perspektywy często uznawana za przełom w świecie sztuk plastycznych. Odpowiednikiem Poematu w świecie teatru była prapremiera sztuki Jerzego Lutowskiego Ostry dyżur, zaprezentowana po raz pierwszy z okazji 22 lipca, poświęcona konfrontacji dwóch postaw działaczy partyjnych. $\mathrm{Z}$ tego względu nie mogła być wystawiana poza Warszawą bez zgody lokalnych władz, a recenzje ze spektaklu zostały dopuszczone do druku dopiero dwa tygodnie po premierze ${ }^{110}$. Jesienią na łamach prasy zaczęła toczyć się ożywiona dyskusja na temat sytuacji nauki, znaczenia w niej marksizmu i przełamywania barier krępujących rozwój nauk humanistycznych zainicjowana przez socjologa Józefa Chałasińskiego ${ }^{111}$. Do końca roku wypowiedzieli się w niej, niektórzy kilkakrotnie, m.in.: Adam Schaff, Władysław Bieńkowski, Bogdan Suchodolski, Leszek Kołakowski, Tadeusz Kroński, Andrzej Walicki i Oskar Lange ${ }^{112}$.

${ }^{109}$ W. Władyka, Na czołówce. Prasa w październiku..., s. 34-37; J. Detka, W cieniu Poematu dla dorostych. O poematach rozrachunkowych czasu odwilży, w: Październik 1956 w literaturze i filmie, red. M. Zawodniak, P. Zwierzchowski, Bydgoszcz 2010, s. 79-91.

${ }^{110}$ M. Napiontkowa, op. cit., s. 67.

${ }^{111}$ J. Chałasiński, Inteligencja ludowa, „Nauka Polska” 1954, nr 4; idem, Zagadnienia kultury wspótczesnej w humanistyce polskiej, „Nauka Polska” 1955, nr 2.

112 Dyskusja toczyła się na łamach „Przeglądu Kulturalnego”: A. Schaff, O badaniach kultury i o szkołach w nauce, „Przegląd Kulturalny” 1955, nr 37, s. 1, 4; idem, Jak kształcić młode kadry naukowe, ibidem, nr 38, s. 1-2; J. Chałasiński, Spór o rozumienie kultury, ibidem, nr 39, s. 1-2; idem, Kultura umysłowa i jej autorytety, ibidem, nr 41, s. 1, 5; W. Bieńkowski, W poszukiwaniu prawdy, czyli na czym budować nasza humanistykę, ibidem, nr 41, s. 1, 4; B. Suchodolski, O upowszechnienie pracy naukowej, ibidem, nr 42, s. 4; L. Kołakowski, Wizjonerstwo i dogmatyzm, ibidem, nr 43, s. 1-2; A. Schaff, Marksizm a rozwój polskiej humanistyki, ibidem, nr 44, s. 1, 4; B. Suchodolski, Teoria kultury i rewolucja socjalistyczna, ibidem, nr 44, s. 3, 5; A. Schaff, O pozytywny program badań społecznych, ibidem, nr 45, s. 1-2; B. Suchodolski, Teoria kultury i nasza polityka kulturalna, ibidem, $\mathrm{nr} 45$, s. 4; A. Schaff, O roli partii w rozwoju teorii marksistowskiej, ibidem, $\mathrm{nr} 47$, s. 7; T. Kroński, Antydogmatyzm i metafizyka, ibidem, nr 46, s. 2, 4-5; A. Walicki, Dwie metafi$z y k i$, ibidem, $\mathrm{nr} 48, \mathrm{~s}$. 2; O. Lange, O konsekwentne stosowanie analizy marksistowskiej, ibidem, $\mathrm{nr}$ 49, s. 1-2; B. Leśnodorski, W sprawie dalszego rozwoju naszej humanistyki, ibidem, nr 51-52, s. 1-2; Z. Rykowski, W. Władyka, op. cit., s. 103-104. 
Berman, Morawski, Werfel i Żółkiewski spotkali się z redakcjami „Nowej Kultury” i „Przeglądu Kulturalnego” w maju 1955 r. Ukazanie się Poematu Ważyka było dowodem, że takie spotkania z przedstawicielami najwyższych władz nie mają już tej mocy co dawniej. W czasie narady aktywu partyjnego literatów z udziałem Bermana, Ochaba i Morawskiego 23 września w warszawskim Pałacu Staszica, pod adresem wiersza, poety i redakcji kierownictwo partii oddało najcięższe salwy. Partyjny rytuał wymagał, by następni mówcy piętnowali i odcinali się od winowajców, którzy powinni złożyć samokrytykę i oddać się w ręce partii. Istotne novum polegało na tym, że w czasie narady padały także głosy broniące prawa poety do autorskiego, choć z pozycji partyjnych, przetworzenia rzeczywistości ${ }^{113}$. Taka była linia obrony autora oraz redaktora naczelnego „Nowej Kultury”. Był nim Paweł Hoffman - człowiek związany z ruchem komunistycznym od 1921 r., w KPP od 1927 r., więziony, członek centralnej redakcji KPP, w czasie wojny w ZSRR, redaktor i publicysta "Nowych Widnokręgów” w okupowanym Lwowie, po wojnie redaktor naczelny „Rzeczpospolitej” i „Kuźnicy”, a w latach 1950-1954 kierownik Wydziału Kultury KC PZPR. Zatem jeden z zaufanych, człowiek o samodzielnej pozycji i szerokich znajomościach wśród najważniejszych ludzi władzy, o autorytecie w kręgu kapepowskim, ze stażem dłuższym niż Berman, dla którego niezależnie od niższego miejsca w formalnej hierarchii - był partnerem. Według wielu świadectw Hoffman, publikując Poemat, świadomie stworzył fakt dokonany, chciał przyspieszyć i pogłębić odwilż ${ }^{114}$.

Załamywanie się kontroli partii nad środowiskiem literatów, artystów - i szerzej - intelektualistów, czego objawem był Poemat dla dorosłych - to jedno. Ale to, że kierownictwo partii generalnie było gotowe pozwolić literatom na więcej niż dziennikarzom i prasie, postrzeganym jako propagandowe ramię partii to drugie. Dotyczyło to w szczególności działaczy, którzy sprawowali funkcje redaktorów. Ważyk nie poniósł więc żadnych konsekwencji, nie został usunięty z partii (a nawet wkrótce otrzymał nagrodę państwową), ale Hoffman został odwołany z funkcji redaktora naczelnego. Oficjalną linię partii interpretował na łamach „Życia Partii” Żółkiewski: potępił krytykę w takiej formie jak ta Ważyka oraz politykę redakcyjną czasopism literackich, głównie „Nowej Kultury”, pisał też o potrzebie oddziaływania ideologicznego na środowiska twórcze.

Obnażona w Poemacie ponura rzeczywistość Nowej Huty zmusiła Biuro Polityczne do reakcji w obronie wiarygodności oficjalnie zadekretowanej walki z biurokratycznymi „wypaczeniami”. Politbiuro ostro skrytykowało lokalne władze w Nowej Hucie, zarzucając im naruszenie dyscypliny partyjnej, łamanie uchwał partii, hamowanie krytyki. Prasie zwrócono uwagę, że w artykułach obok „słusznie

113 AAN, KC PZPR, XIA/138, Notatki z narady aktywu partyjnego literatów z kierownictwem partii, 23 IX 1955 r., k. 1-8; Z. Rykowski, W. Władyka, op. cit., s. 100-104.

${ }^{114}$ Rozmowa z Jerzym Morawskim..., s. 164-165; T. Chrząstek, op. cit., s. 194-199; T. Mielczarek, Od „Nowej Kultury” do „Polityki”..., s. 122-124. 
podanych faktów i sygnałów są pewne niesprawdzone fakty oraz szereg błędnych i panikarskich sformułowań"115. Co ciekawe, burza wywołana przez Poemat nie została zasygnalizowana na łamach biuletynu Sektora Prasy KC. Formalnie rzecz biorąc, mogło być to konsekwencją odrębnego statusu pism literackich należących do Związku Literatów Polskich. Równie prawdopodobne, że był to rezultat decyzji podjętej na wysokim szczeblu.

Sprawa Poematu miała dużo większe znaczenie dla partyjnej inteligencji niż przeciętnego czytelnika, sięgającego najczęściej po prasę codzienną, a w mniejszym stopniu po tygodniki literackie. Dyskusja wokół utworu Ważyka i brak dotkliwych kar za jego publikację ośmieliły jednak wielu redaktorów gazet ogólnopolskich, co miało przełomowe znaczenie dla obrazu prasy zauważalnego dla wszystkich: od tego momentu cenzura zaczęła notować stały wzrost ingerencji o charakterze politycznym. Według kierownictwa GUKPPiW do wczesnej jesieni $1955 \mathrm{r}$. ingerencje w publikacje (z wyjątkiem katolickich) praktycznie nie dotyczyły kwestii politycznych i ograniczały się do tzw. tajemnic państwowych. Znane były nawet przypadki książek, które miały zgodę urzędu na druk, a mimo to leżały w wydawnictwach i ukazały się dopiero jesienią 1956 r. - co także dla cenzorów było dowodem na skuteczność „cenzora wewnętrznego”. Właśnie jesienią 1955 r. kierownictwo urzędu z ul. Mysiej zaczęło wydawać biuletyn „Sygnały” z wszystkimi skonfiskowanymi materiałami, by zapoznawać przywódców partii z sytuacją w prasie i umożliwiać bieżące kontrolowanie „linii” cenzorskiej. Niewykluczone, że chodziło też o przygotowanie przez kierownictwo urzędu alibi w przypadku pojawienia się zarzutów o zbytni liberalizm, względnie zbytnią surowość. Stojący na jego czele Marian Mikołajczyk - szeregowy cenzor, który pokonał wszystkie szczeble w urzędzie, pracując w nim od 1945 r., nie miał samodzielnej pozycji politycznej w aparacie władzy i mógł być tylko wykonawcą poleceń z "góry”116. Kierownictwo GUKPPiW w notatce z grudnia 1956 r., w której apelowało do Biura Politycznego o wsparcie w obliczu ataków kwestionujących sens istnienia cenzury, przekonywało, że na przestrzeni ostatniego roku żaden z odbiorców „Sygnałów” nie miał uwag krytycznych, wręcz przeciwnie, członkowie kierownictwa niejednokrotnie „dawali wyraz aprobaty dla naszej działalności”"117. Oznaczałoby to,

115 AAN, KC PZPR, V/30, Protokół posiedzenia BP, 18 X 1955 r., k. 87-88.

116 Marian Mikołajczyk, ur. w 1920 r., w PPR/PZPR od września 1945 r., w latach 1945-1946 referent w Powiatowym Urzędzie Informacji i Propagandy w Zduńskiej Woli i jednocześnie referent powiatowego Urzędu Kontroli Prasy. W latach 1946-1950 w wojewódzkim Urzędzie Kontroli Prasy w Łodzi, awansował z szeregowego cenzora do stanowiska zastępcy naczelnika. W latach 1950-1957 w GUKPPiW jako szef departamentu, zastępca dyrektora i dyrektor, AAN, KC PZPR, CK/XX 4901, k. 63.

117 W 1956 r. Mikołajczyk aż trzykrotnie był bliski odwołania: w kwietniu, bezpośrednio po poznańskim Czerwcu na przełomie czerwca i lipca oraz w pierwszej połowie października. Biuro Polityczne podejmowało decyzje o jego odwołaniu, ale za każdym razem ich wykonanie wstrzymywano. Prezes GUKPPiW być może nie był tego świadom, AAN, KC PZPR V/48, List 
że w okresie ideologicznej niepewności, wymagającym od cenzury szczególnej ostrożności i wyczucia, kierował nią trzeciorzędny urzędnik pozostawiony przez mocodawców sam sobie z decyzjami, które go przerastały. Czy zaryzykowałby bez konsultacji z "górą" zdjęcie tekstu firmowanego przez zasłużonego towarzysza z długim stażem i szerokimi znajomościami? Być może taki jest klucz do wyjaśnienia postępowania cenzorów w 1955 i 1956 r.

Odwołanie Hoffmana nie oznaczało końca problemów władz z „Nową Kulturą". Zarząd główny ZLP, do którego formalnie należał tytuł, jednomyślnie potępił decyzję kierownictwa partii - zaledwie pół roku wcześniej nie do pomyślenia - jako niekonsultowaną i świadczącą o lekceważeniu pisarzy. W głosowaniu w zarządzie głównym ZLP przepadł forsowany przez Bermana na nowego redaktora naczelnego Leon Kruczkowski, gwarantujący zachowanie dyscypliny. Nowy redaktor naczelny, Leon Przemski, początkowo miał status pełniącego obowiązki, został de facto wybrany przez redakcję - co było precedensem - i dopiero w styczniu 1956 r. zatwierdzony na tym stanowisku przez władze. Zapewne nie byłoby to możliwe, gdyby nie chodziło o doświadczonego towarzysza, który spędził wojnę w ZSRR, w 1940 r. pisywał do polskojęzycznego "Czerwonego Sztandaru”"118. Mimo podjętych przygotowań władze zrezygnowały z reorganizacji zespołu redakcyjnego i pacyfikacji pisma ${ }^{119}$. W następnych miesiącach, choć nieco ostrożniej, redakcja $\mathrm{w}$ dalszym ciągu podejmowała tematykę do niedawna zakazaną. W listopadzie 1955 r. członkowie Biura Politycznego zostali poinformowani, że cenzura zatrzymała zaakceptowany już przez redakcję felieton Jerzego Andrzejewskiego $W$ sprawie relatywizmu, pełen pesymizmu, jeśli chodzi o postępy w ujawnianiu „błędów” przez partię ${ }^{120}$.

Trwała jeszcze dyskusja na temat Poematu, gdy do rąk czytelników trafił odnowiony tygodnik „Po Prostu”, który z nudnego pisma - organu Związku Młodzieży Polskiej, co prawda stopniowo odżywającego od wiosny 1955 r., po wakacjach przeobraził się - zgodnie z deklaracją redakcji na nowej zielonej winiecie - w tygodnik „studentów i młodej inteligencji” ${ }^{121}$. Redakcja, od pierwszych powakacyjnych numerów naruszająca kolejne tabu, nie tylko stworzyła pismo adresowane do młodych, a czytane również przez dorosłych, ale szybko zaczęła nadawać ton całej prasie i skupiać wokół siebie tzw. lewicę październikową ${ }^{122}$.

kierownictwa GUKPPiW do Biura Politycznego KC PZPR, 3 XII 1956, k. 83-87. Szerzej zob. P. Sasanka, op. cit..

118 AAN, KC PZPR, CK XX/3154, Akta osobowe Leona Przemskiego.

${ }^{119}$ K. Rokicki, Literaci. Relacje między literatami a władzami PRL w latach 1956-1970, Warszawa 2011, s. 92-97; T. Chrząstek, op. cit., s. 207-213.

${ }^{120}$ AAN, KC PZPR, V/36, Felieton Jerzego Andrzejewskiego, k. 160-164.

121 T. Mielczarek, Od „Nowej Kultury” do „Polityki”..., s. 227-230.

122 W. Władyka, Na czołówce. Prasa w październiku..., s. 38-44; D. Rafalska, Między marzeniami a rzeczywistością...; D. Gawin, op. cit., s. 16-19. 
Jakie były kulisy nowego otwarcia „Po Prostu”, czy ktoś z gmachu KC zapalił zielone światło i jakimi motywami się kierował, czy tygodnik miał swojego patrona w „Białym Domu” - te pytania wciąż pozostają otwarte.

Być może zespół „Po Prostu” dostał zgodę na głębsze zmiany pisma w konsekwencji krytycznej oceny dotychczasowej pracy przygotowanej przez „grupę towarzyszy" w porozumieniu z Sektorem Prasy i dyskusji, jaka miała miejsce w KC 22 kwietnia 1955 r. ${ }^{123}$ Obok nieodzownych rytualnych zaklęć w czasie dyskusji wiele miejsca poświęcono dostrzeganym istotnym słabościom pisma. Zarzucano mu, że „słabo zajmuje się wyjaśnianiem linii partii”, nie podejmuje tematów, którymi żyją studenci i młodzi pracownicy naukowi. W notatce z narady brakowało jednak konkluzji dotyczących postulowanych zmian formuły pisma lub przebudowy zespołu redakcyjnego ${ }^{124}$. Po kilku miesiącach funkcjonowania w nowej odsłonie „Po Prostu” zostało ocenione przez Wydział Kultury i Nauki KC. Jak pamiętamy, wcześniejszej oceny dokonał Sektor Prasy - zmiana zdaje się świadczyć o wadze przykładanej do społeczno-kulturalnej funkcji odnowionego pisma. Wyniki oceny zakomunikowano redakcji w czasie spotkania 3 grudnia 1955 r. Według Marty Fik, redakcji zarzucono nadmierny krytycyzm i brak programu pozytywnego ${ }^{125}$. Realizacja zadania powierzonego wówczas pismu - rozszerzenia tematyki i powiększenia kręgu odbiorców - jak okazało się za kilka miesięcy - przekroczyła najśmielsze oczekiwania zleceniodawców z Komitetu Centralnego ${ }^{126}$.

Ówczesny redaktor naczelny pisma, Eligiusz Lasota, oceniał po latach, że polityczni dysponenci zbagatelizowali sygnały świadczące o emancypacji pisma uważanego za „peryferyjne”. Gdy zaś stało się ono najpoczytniejszym tygodnikiem-instytucją, nie byli już w stanie odzyskać wpływu na jego linię polityczną ${ }^{127}$. „Kiedy zaczęliśmy «rozbijać» - jak oni uważali - ZMP, próbowali nas hamować. Zresztą niezbyt konsekwentnie" - wspominał, dodając, że w Komitecie Centralnym mieli grono sympatyków. „Niektórzy, choć nam sprzyjali, zachowywali pewną rezerwę: mimo że uważali kierunek naszych działań za słuszny, szokowała ich nasza bezkompromisowość, zarzucali nam żywiołowość”128.

${ }^{123}$ Byli dziennikarze „Po Prostu” nie wspominali o ocenie czasopisma przez KC, kładli nacisk na dyskusję wewnątrz redakcji, B.N. Łopieńska, E. Szymańska, Stare numery, Londyn 1986, s. 35-40. Por. D. Rafalska, Między marzeniami a rzeczywistością..., s. 26-27, 31.

${ }^{124}$ AAN, KC PZPR, 237/VIII/363, Biuletyn nr 3 Sektora Prasy, 25 IV 1955 r., k. 30.

${ }^{125}$ M. Fik, op. cit., s. 223.

${ }^{126}$ AAN, KC PZPR, 237/XVI/207, Uwagi Wydziału Kultury i Nauki KC do tygodnika „Po prostu”, grudzień $1955 \mathrm{r}$.

127 A. Kozieł, Studium o polityce prasowej..., s. 110.

${ }^{128}$ Relacja ze spotkania z Eligiuszem Lasotą w Instytucie Dziennikarstwa UW, 21 III 1986 r., w: Materiały pomocnicze do historii dziennikarstwa Polski Ludowej, t. 14, red. A. Słomkowska przy współpracy D. Mikołajczyk-Grzelewskiej, Warszawa 1991, s. 296. 
Jesienią (21 października - 9 listopada 1955 r.) grupa pracowników Sektora Prasy wybrała się w podróż studyjną do ZSRR, by podglądać tamtejsze metody zarządzania propagandą i przygotować się do pracy w nowych ramach organizacyjnych, wprowadzanych w ślad za zmianami w aparacie propagandowym KPZR i KPU. Po powrocie sporządzili obszerne sprawozdanie przedstawiające zmiany w strukturze i sposób funkcjonowania Wydziału Propagandy KC KPZR. Obszerny passus poświęcono zrelacjonowaniu spotkania z zarządcami tamtejszego „frontu propagandowego", w tym ich generalnie dość krytycznych ocen zawartości prasy w „ojczyźnie światowego proletariatu” i sugestii w tej materii dla polskich towarzyszy. Anonimowy czytelnik sprawozdania zakreślił fragment wypowiedzi zastępcy redaktora naczelnego „Prawdy”, Pawła Satiukowa, mówiącego o społecznej celowości informacji: „Nie uważa on np. za potrzebne informowanie o wypadkach, nawet o powodzi w Leningradzie ${ }^{129}$. Należy walczyć o szybkość informacji. Nie wolno pozostawać w tyle za Zachodem, jeśli idzie o szybkość informacji. Nie powinniśmy uciekać przed trudnościami, ale nie możemy zapełniać gazet sprawą trudności. Należy mówić o trudnościach trzeźwo, zważając na możliwości ich usunięcia"130.

Po powrocie wycieczki do kraju, 16 listopada podjęto decyzję o przeprowadzeniu analogicznych do tych w Związku Sowieckim zmian w strukturze Komitetu Centralnego PZPR. Nadzór nad prasą, radiem i wydawnictwami, wyłączonymi z kompetencji Wydziału Propagandy i Agitacji, przekazano do utworzonego Wydziału Prasy, Radia i Wydawnictw (podzielonego na trzy sektory, w tym prasy ${ }^{131}$. Na jego czele stanął były redaktor naczelny gazet partyjnych, Tadeusz Galiński, przechodzący ze stanowiska przewodniczącego Komitetu ds. Radiofonii „Polskie Radio"132.

Pod koniec 1955 r. sygnałem do ponownego zaostrzenia kursu wobec prasy była krytyka „Trybuny Ludu”, oficjalnego organu KC PZPR - zamieszczane na jej łamach artykuły były traktowane jako wykładnia oficjalnego stanowiska KC partii. Redagowana przez najpewniejszych towarzyszy gazeta była pod szczególną pieczą Biura Politycznego. Berman często weryfikował artykuły przez drukiem i osobiście dzwonił do redaktora naczelnego. Zapewne ze względu na niewystarczająco stanowczą odpowiedź ${ }^{133}$ na Poemat dla dorosłych kierownictwo partii uznało, że wypełnianie przez „Trybunę” roli centralnego organu KC, który nadaje ton

\footnotetext{
${ }^{129} \mathrm{Na}$ przestrzeni 308 lat (1703-2011), do czasu uruchomienia systemu przeciwpowodziowego, w mieście odnotowano 308 powodzi i podtopień. J. Czeczott, Petersburg. Miasto snu, Wołowiec 2017.

${ }^{130}$ AAN, KC PZPR, 237/VIII/363, Sprawozdanie grupy pracowników Sektora Prasy i Wydawnictw z wyjazdu do ZSRR, 25 XI 1955 r., k. 166-190.

131 E. Grygo, Z problematyki kierownictwa prasa PZPR..., s. 71.

${ }^{132}$ AAN, KC PZPR, V/30, Protokół nr 83 posiedzenia Sekretariatu KC, 16 XI 1955 r., k. 276-277.

${ }^{133}$ B. Czeszko, Deliberacje nad „Poematem dla dorostych”, „Trybuna Ludu” 4 IX 1955; J. Rawicz, Prawdy i nieprawdy, „Trybuna Ludu” 12 X 1955.
} 
prasie partyjnej w obliczu rysującego się kryzysu, stanęło pod znakiem zapytania. W opinii Politbiura gazeta nie ustrzegła się publikacji artykułów postrzeganych jako odstępstwo od linii partii ${ }^{134}$. Informację o negatywnej ocenie przekazano redakcji i dziennikarzom $\mathrm{w}$ terenie, a tekst dokumentu zamieszczono w biuletynie Sekretariatu $\mathrm{KC}^{135}$. Od tego momentu zarzuty bierności pod adresem prasy partyjnej, a w szczególności oficjalnego organu KC, będą podnoszone przy wielu okazjach.

Kierownictwo uznało, że „Trybuna Ludu” potrzebuje pomocy. Po pierwsze, wzmocnienia kilkoma osobami działu ideologicznego i jego systematycznych narad z całą redakcją. Sekretariat KC zdecydował o powierzeniu stanowiska zastępcy redaktora naczelnego i kierownika działu ideologicznego w „Trybunie” Leszkowi Krzemieniowi. Urodzony w 1905 r. Krzemień był - jak trafnie ujął to Andrzej Friszke - towarzyszem najważniejszych towarzyszy, z równie długim - jeśli nie dłuższym - stażem partyjnym. Od 1921 r. był bardzo aktywny w Komunistycznym Związku Młodzieży Polskiej i należał do jego kierownictwa ${ }^{136}$. Od $1924 \mathrm{r}$. w KPP, studiował w Międzynarodowej Szkole Leninowskiej (1928-1931) niemal w tym samym okresie co Zambrowski i Bierut, który do jesieni 1929 r. był starostą polskiej grupy słuchaczy ${ }^{137}$. Został przyjęty do WKP(b) z zaliczeniem stażu od 1924 r. Przed wojną spędził łącznie blisko dziewięć lat $\mathrm{w}$ więzieniach $\mathrm{z}$ powodu działalności komunistycznej. Po wojnie głównie na „odcinku” wojskowym, z którego - jako zaufany - został czasowo oddelegowany do „Trybuny Ludu”"138. Warto zauważyć, że dwie jego siostry, również komunistki, były ofiarami wielkiej czystki w ZSRR: jedna została zamordowana w 1937 r., druga skazana na kilka lat łagru. Jego akta personalne zawierają kilka wzmianek świadczących o dystansie wobec skrajnej ortodoksji. Na przykład w lipcu 1944 r. jako oficer polityczny złożył do Centralnego Biura Komunistów Polskich samokrytykę w związku z zarzutami o podpisanie okólnika, w którym posługiwanie się językiem rosyjskim określił działalnością „obiektywnie wrogą w stosunku do narodu polskiego"139.

${ }^{134}$ M. Szumiło, Działalność redakcji „Trybuny Ludu” w 1955 roku w świetle raportu ambasadora sowieckiego w Warszawie, „Res Historica” 2013, nr 36, s. 303-305.

${ }^{135}$ AAN, KC PZPR, V/30, Protokół posiedzenia BP, 17 XI 1955 r., k. 101; ibidem, V/31, Węzłowe problemy „Trybuny Ludu” z uchwały BP KC PZPR, 17 XI 1955 r., k. 161-171.

${ }_{136}$ Zob. L. Krzemień, Kropla w potoku, Warszawa 1963.

${ }^{137}$ M. Szumiło, Wspomnienia Romana Zambrowskiego z Międzynarodowej Szkoły Leninowskiej w Moskwie (1929-1931), „Komunizm. System - ludzie - dokumentacja” 2012, nr 1, s. 169.

${ }^{138}$ Leszek Krzemień, właść. Maksymilian Wolf (1905-1997), działacz KZMP od 1921 r., w KPP m.in. kierownik wydziału wojskowego KC KPP, w ZSRR od 1939 r., oficer polityczny WP, szef misji wojskowej w Wiedniu, szef Kancelarii Wojskowej Prezydenta KRN Bieruta (1946-1947), wiceminister obrony narodowej, zastępca dowódcy Śląskiego Okręgu Wojskowego (1948-1950), zastępca szefa GZP WP (1950-1954), szef polskiej misji w Międzynarodowej Komisji Kontroli i Nadzoru w Korei, zastępca redaktora naczelnego „Trybuny Ludu” od grudnia 1955 do kwietnia 1957 r., pełnomocnik rządu PRL ds. pobytu wojsk radzieckich w Polsce (1957-1968).

${ }^{139}$ AAN, KC PZPR, CK XX/4832, Akta osobowe Leszka Krzemienia. 
Drugim zakładanym elementem wsparcia „Trybuny Ludu” była przewidziana „ofensywa ideologiczna” - seria artykułów, które mieli napisać członkowie ścisłego kierownictwa i w ten sposób wyznaczyć na busoli obowiązujący kurs. Artykuły miały się ukazywać do kwietnia 1956 r.; dość szczegółowo ułożono plan na grudzień i styczeń. Planowano, że na początku roku wypowiedzą się najważniejsi: Bierut (O moralności komunistycznej) i Berman (Przeciw dogmatyzmowi, o twórczy rozwój marksizmu - bilans roku ubiegłego). Najwięcej artykułów miało wyjść spod pióra Werfla (m.in. Dogmatyzm i rewizjonizm, Prawda obiektywna podstawa marksizmu). Dyskusję na łamach „Przeglądu Kulturalnego” mieli skomentować Bronisław Baczko lub Leszek Krzemień. Artykuł wyznaczający ramy dla krytyki miała napisać Romana Granas (Rozwijać twórczą krytykę, przeciwstawić się krytykanctwu), zaś na temat aktualnego postrzegania ram dyscypliny partyjnej Walenty Titkow (O centralizmie demokratycznym. Przeciw żywiołowości i komenderowaniu, za właściwe kierownictwo w życiu partii). Tematami gospodarczymi miał się zajmować Eugeniusz Szyr, zaś polityką międzynarodową Seweryn Bialer (który już w styczniu 1956 r. uciekł z PRL na Zachód) ${ }^{140}$. Choć Biuro Polityczne zatwierdziło program „ofensywy ideologicznej” 3 stycznia 1956 r. z niewiadomych przyczyn nie ukazał się ani jeden z planowanych artykułów. Być może zdano sobie sprawę z nieuniknionego fiaska „ofensywy ideologicznej” w atmosferze odwilży, może autorzy - jak Werfel lub Granas - sygnalizowali narastające wątpliwości? O zamęcie na "froncie ideologicznym” świadczyło to, że z perspektywy kierownictwa zaczął błądzić nawet główny ideolog PZPR - Adam Schaff, w którego jednym z artykułów Politbiuro dopatrzyło się licznych „błędnych sformułowan”” ${ }^{141}$.

W połowie grudnia 1955 r. powstała kolejna notatka odnotowująca publikację na łamach „Trybuny Ludu” artykułów, które - jak oceniano - wywołują w czytelniku poczucie beznadziejności i bezradności partii wobec „działań tych czy innych klik lub jednostek, wykorzystujących funkcje partyjne lub państwowe w celach osobistych interesów"142. Na początku 1956 r. sowiecki ambasador w Warszawie sporządził i przesłał do centrali notatkę, w której pod adresem „Trybuny” i jej naczelnego sformułował ciężkie, poparte wieloma przykładami, oskarżenia o odstępstwa od kanonicznej - wyznaczanej przez Moskwę - interpretacji marksizmu-leninizmu w dziedzinie ideologii, kultury i sztuki ${ }^{143}$.

Podobne zarzuty jak w przypadku „Trybuny Ludu” w grudniu sformułowano pod adresem partyjnego pisma teoretycznego „Nowe Drogi”, w którego redakcji pojawiły się już niepokojące kierownictwo rozbieżności w ocenie poszczególnych

\footnotetext{
${ }^{140}$ AAN, KC PZPR, V/36, Notatka w sprawie pracy działu ideologicznego „Trybuny Ludu”, b.d., k. $167-170$.

${ }^{141}$ A. Schaff, O pozytywny program badań społecznych, „Przegląd Kulturalny” 1955, nr 1-2; AAN, KC PZPR, V/30, Protokół nr 66 posiedzenia BP, 17 XI 1955 r., k. 104.

142 AAN, KC PZPR, V/36, Notatka, 16 XII 1955 r., k. 166.

${ }^{143}$ M. Szumiło, Działalność redakcji „Trybuny Ludu”..., s. 301-311.
} 
artykułów. Autor oceny stanowiącej punkt wyjścia dyskusji nie ukrywał nawet, że otrzymał zadanie znalezienia przede wszystkim mankamentów pisma, a nie oceny jego dorobku i tylko półgębkiem przyznawał, że ma ono również pewne osiągnięcia ${ }^{144}$. W protokołach $\mathrm{z}$ obu posiedzeń Politbiura odnotowano nazwiska zabierających głos w dyskusji członków kierownictwa. Na temat „Trybuny Ludu” wypowiadali się (według kolejności zapisanej w protokole): Berman, Franciszek Jóźwiak, Ochab i Morawski, zaś na temat „Nowych Dróg”: Ochab, Jóźwiak, Werfel, Morawski, Minc, Zambrowski, Berman i Cyrankiewicz. Niestety nie wiemy, jak rozkładały się głosy i czy oceny były przedmiotem sporu ${ }^{145}$.

Uchwałę Biura Politycznego w sprawie „Trybuny Ludu” omawiano na serii narad. 23 listopada 1955 r. redaktorzy naczelni prasy warszawskiej spotkali się z Morawskim, a 3 grudnia podobne spotkanie odbyli redaktorzy prasy partyjnej $\mathrm{z}$ terenu. W czasie pierwszego spotkania prominentni przedstawiciele środowiska wypowiadali się w sposób wyważony, ale ich słowa miały wydźwięk alarmowy. Korotyński napomknął o radykalizacji nastrojów, gdy przyznał, że w redakcji istnieje pogląd: „hańba temu dziennikarzowi”, który nie pisze krytycznych artykułów i sam apelował, by w tekstach dotyczących kwestii gospodarczych przyznać, „że błądziliśmy, że błądzili również nasi kierownicy”. Ówczesny redaktor naczelny "Szpilek” Arnold Mostowicz, mając na myśli młodych dziennikarzy i wyrażane już przez nich poglądy, z zaniepokojeniem sygnalizował pojawienie się „drugiego nurtu życia dziennikarskiego", który nie jest należycie kontrolowany przez partię. Oceniał, że młodzi „patrzą często na życie jedynie przez [pryzmat] listów czytelników".

Opinia ta znalazła natychmiastowe potwierdzenie $\mathrm{w}$ wypowiedzi przedstawiciela redakcji „Sztandaru Młodych”, którym był Zdzisław Piś. Chyba po raz pierwszy zdarzyło się, by dziennikarz na forum publicznym otwarcie przyznał, że nie zgadza się z „ujęciem krytyki” dokonanym przez Morawskiego i Korotyńskiego; co więcej zapowiadał, że jego redakcja zamierza polemizować z zamieszczonym w „Życiu Partii” artykułem sekretarza zarządu głównego ZMP. Na obecnych musiało zrobić wrażenie jego żądanie - jak zapisano expressis verbis - by „towarzysze z kierownictwa Partii pisali na łamach prasy o sprawach, które bolą społeczeństwo". Swą wypowiedź zakończył krytyką Wydziału Propagandy KC ${ }^{146}$.

W czasie narady 3 grudnia $\mathrm{z}$ redaktorami naczelnymi prasy partyjnej okazało się, że dziennikarze, którzy zapoznali się już z rozesłanym wcześniej tekstem

144 AAN, KC PZPR, 237/VIII/363, Uwagi krytyczne o „Nowych Drogach” nr 1-10/1955, 21 XI 1955 r., k. 196-201.

145 AAN, KC PZPR, V/30, Protokół nr 69 posiedzenia BP, 8 XII 1955 r., k. 108; ibidem, V/36, Notatka o pracy „Nowych Dróg”, k. 172-183; ibidem, Notatka z dyskusji w INS na temat „Nowych Dróg”, k. 184-195; ibidem, Uwagi o „nowych Drogach”, k. 196-212; ibidem, Wnioski w sprawie pracy redakcji „Nowych Dróg”, k. 213-216.

${ }^{146}$ AAN, KC PZPR, 237/VIII/363, Biuletyn Sektora Prasy nr 20, 14 XII 1955 r., k. 202-217. 
uchwały w sprawie „Trybuny Ludu” niechętnie zabierali głos, a gdy to robili, był on sceptyczny - co wymownie świadczyło o środowiskowej ocenie próby przykręcenia śruby. W ogóle nie pojawił się wątek politycznej roli prasy, za to po raz kolejny wiele miejsca poświęcono narzekaniu na brak wsparcia władz i bezkarność „dławicieli krytyki”. W sprawozdaniu otwarcie przyznano, że w zespołach redakcyjnych panuje dużo nerwowości i zamieszanie. $Z$ tego powodu pracownicy wydziału odbyli serię wyjazdów do redakcji w Stalinogrodzie (Katowicach), Krakowie, Łodzi, Wrocławiu, Poznaniu i Szczecinie. Relacje z tych narad również świadczyły o panującym zamęcie i zróżnicowaniu środowiska.

W sprawozdaniu odnotowano, że w redakcjach w Warszawie, zgodnie z oczekiwaniem „góry”, potępiano „modę na krytykę”, jaka rzekomo zapanowała po III posiedzeniu plenarnym KC. Narzekano, że w redakcjach ceni się bardziej „autora materiału krytycznego, artykuły krytyczne szybko przedostają się na łamy gazet, a z innymi materiałami jest znacznie trudniej”. Padały głosy, które - jak to ujęto w sprawozdaniu - „najlapidarniej ujął towarzysz Mazurek mówiąc, że «dziennikarz zbiera materiał i rozmawia z ludźmi trochę z pozycji prokuratora»". Oficjalnie dziennikarze szukali winy w sobie, mówili o swojej „niedojrzałości”, nawale spraw, szczupłości zespołów, złej organizacji pracy redakcji.

Ważniejsze było to, że nieoficjalnie mówili zupełnie co innego: że nie tylko nie mają żadnego wsparcia ze strony komitetów wojewódzkich i są przez nie krępowani. W redakcjach peryferyjnych (np. „Nowinach Rzeszowskich”) coraz więcej było głosów podważających w ten czy inny sposób wytyczne zwierzchników. Słychać było apele o odwoływanie posłów i radnych niewywiązujących się ze swych zadań oraz karanie instytucji za niezałatwianie spraw. Mówiono o czytelnikach, którzy wierzą jedynie redakcji, a nawet jednemu felietoniście. Podawano kolejne przykłady presji wywieranej przez komitety wojewódzkie PZPR na prasę: „Nie wyjaśniono trudności w zaopatrzeniu w węgiel. Nie wyjaśniono trudności w zaopatrzeniu w kartofle. Komitet Wojewódzki wychodził z założenia, że gazety nie powinny poruszać tych spraw”. Sloganowe hasło rzucone w czasie zebrania redakcji „Chłopskiej Drogi”: „krytyka prasowa musi «iść razem z partią»" sprowokowało kilka osób do stwierdzenia, iż oznacza to rezygnację z inicjatywy dziennikarza, rezygnację z wykorzystania inicjatywy krytycznej czytelnika i korespondenta, odcina więc partię od mas”. W czasie narady redakcji „Głosu Robotniczego" w wypowiedziach grupy młodych i - co podkreślano - zdolnych dziennikarzy „przebijało rozdrażnienie, żądanie publikowania całej prawdy, pisanie o wszystkich świństwach, chęć monopolizowania walki z krzywdą" ${ }^{447}$.

U progu 1956 r. znaczna część środowiska warszawskich dziennikarzy, w większości młodych ludzi, nie widziała się już, jak dotychczas, w roli bezwolnego

${ }_{147}$ AAN KC PZPR, 237/VIII/363, Biuletyn Sektora Prasy nr 19 i 20, 5 i 14 XII 1955 r., k. 191-194, 205-212. 
narzędzia partii i jej propagandowej tuby. Dla wielu z nich, ukształtowanych przez ideologię, a zarazem świadomych rozmijania się teorii ze stalinowską rzeczywistością, kierownictwo partii nie było już bezdyskusyjnym autorytetem jeśli chodzi o kierunek zmian i funkcjonowanie prasy. Coraz odważniej wyrażali swoje opinie na oficjalnych zebraniach, coraz częściej ich punktem odniesienia nie była partia, ale czytelnicy. Nie znaczy to, że młodzi dziennikarze z radykalnie lewicową perspektywą rozumieli poglądy i postawy przytłaczającej większości społeczeństwa, w swej masie antykomunistycznego, religijnego i konserwatywnego; by mogli i chcieli wyrażać wszystkie społeczne emocje. Niemniej jednak, tam, gdzie naruszali kolejne obszary tabu i demaskowali rzeczywiste oblicze systemu stalinowskiego w Polsce, tam wychodzili naprzeciw autentycznemu społecznemu oczekiwaniu.

Odzwierciedlały to nakłady rosnące w drugiej połowie $1955 \mathrm{r}$. W październiku odnotowano wzrost w stosunku do września „Trybuny Ludu” o 4,7\%, „Gazety Białostockiej” o 11\%, „Głosu Szczecińskiego” o 8\%, „Głosu Robotniczego” o 6\%, „Sztandaru Młodych” o 12,2\%. Z czasopism partyjnych o 6,4\% spadł nakład „Trybuny Wolności”. Wyraźnie zaczęły rosnąć nakłady czasopism kulturalnych, odwilżowej forpoczty: w listopadzie w porównaniu do października nakład „Nowej Kultury” wzrósł o niemal 14,3\% i „Przeglądu Kulturalnego” o ponad 16,6\% ${ }^{148}$. Gdy 19 grudnia 1955 r. Wydział Prasy, Radia i Wydawnictw zorganizował konferencję redaktorów naczelnych $\mathrm{z}$ Warszawy poświęconą zadaniom prasy w czasie dyskusji nad projektem kolejnego planu pięcioletniego, w jej trakcie - jeśli wierzyć zapisowi - nie było mowy o poleceniach. $Z$ tego okresu znamy tylko kilka zachowanych telefonogramów, brakuje m.in. pisemnych wytycznych do kampanii propagandowej po poznańskim Czerwcu i procesów sądowych jego uczestników. Nie jest jasne, $\mathrm{w}$ jaki stopniu wynika to z przetrzebienia archiwów, a w jakim $\mathrm{z}$ telefonicznego przekazywania "nastawienia” redakcjom $^{149}$.

Kryzys ideologiczny i niesubordynacja partyjnych środowisk twórczych skłoniły kierownictwo partii do przeciwdziałania. Sięgnęło ono do metody sprawdzonej w przeszłości i w dniach 20 i 23 grudnia 1955 r. zorganizowało naradę tzw. pionu ideologicznego PZPR z udziałem ponad setki funkcjonariuszy partyjnych, partyjnych literatów, dziennikarzy, ludzi nauki i sztuki. O dużej randze narady świadczył nadzwyczajnie liczny udział członków „szerokiego” kierownictwa, obecni byli: Berman, Cyrankiewicz, Minc, Aleksander Zawadzki, Zenon Nowak, Ochab, Jóźwiak, Matwin, Morawski i Zambrowski. Zwraca uwagę nieobecność w tym gronie Bieruta - być może celowa, by nie powtórzyła się sytuacja z burzliwej narady z listopada $1954 \mathrm{r}$. Zwraca też uwagę, że obecni tak licznie towarzysze z kierownictwa w zasadzie nie zabierali głosu, co można interpretować jako oddanie

\footnotetext{
148 AAN, KC PZPR, 237/VIII/363, Biuletyn Sektora Prasy nr 19, 5 XII 1955 r., k. 195.

149 AAN, KC PZPR, 237/XIX/68, Telefonogram, 22 XII 1955 r., k. 1.
} 
pola, ale też pewne zdystansowanie się. Głównym mówcą był Berman, który po kilku słowach ogólnej charakterystyki ideowego zamętu i oszczędnej samokrytyki przeszedł do frontalnego ataku na środowiska partyjnych intelektualistów, ludzi kultury i sztuki. Sformułował go stalinowskim językiem, który jeszcze niedawno terroryzował odbiorców, ale na przełomie 1955 i 1956 r. brzmiał już trochę anachronicznie i stracił dużo ze swej niedawnej mocy. Z pozycji ortodoksyjnego strażnika czystości ideologii komunistycznej Berman wyliczał przypadki odstępstw, zarzucając im wszystkim publiczne zakwestionowanie prymatu ideologii nad swobodą twórczą, czyli wpływ partii na literaturę i sztukę. Zaatakował z nazwiska socjologa Józefa Chałasińskiego, literatów i krytyków literackich: Adama Ważyka, Jerzego Andrzejewskiego, Antoniego Słonimskiego, Artura Sandauera, Jana Błońskiego, Jana Kotta, Ludwika Flaszena. Szczególnie ostro, jako odpowiedzialnych za ten stan rzeczy, napiętnował starych komunistów oddelegowanych na „odcinek” kulturalny: Pawła Hoffmana i Jadwigę Siekierską. Postawił im najcięższy i - dla wierzących komunistów - najbardziej bolesny zarzut: że swoją postawą wyrządzili partii dużą szkodę.

Berman próbował narzucić jedyną wykładnię i bronił pozycji głównego ideologa PZPR, ale ta wyraźnie słabła. Opierała się na poważaniu, jakie miał w kręgach kapepowskich, żelaznej dyscyplinie partyjnej i strachu. Z tych trzech elementów dwa ostatnie kruszyły się. Atakując Hoffmana i Siekierską, Berman rzucił na szalę swój autorytet, ale nie zostało to dobrze przyjęte, bo wyraźnie przekroczył granice: Siekierska należała do garstki polskich komunistów, którzy cudem przeżyli rzeź urządzoną im w 1937 r. w ZSRR przez Stalina. Została wtedy aresztowana jako „członek rodziny zdrajcy ojczyzny”, spędziła wojnę w łagrach, dwójka jej rodzeństwa, również komunistów, została w ZSRR zamordowana ${ }^{150}$. Po 1945 r. nadzorowała różne sfery życia kulturalnego, w czasie odwilży wyraźnie przewartościowała poglądy i opowiedziała się przeciwko partyjnemu administrowaniu kulturą.

Berman wiele miejsca poświęcił niepokojącym objawom w środowisku literackim i potrzebie „wyprostowania linii” czasopism literackich. Wychodząc naprzeciw nastrojom, jednak dystansował się od współtworzonego przez siebie modelu i odrzucał ,prostackie pojmowanie literatury jako sloganowej propagandy ubranej w formę artystyczną". Obiecywał, że władze chcą „unikać drobiazgowej ingerencji w sprawy literatury, posługiwać się zaś głównie inspiracją i ogólnym oddziaływaniem ideologicznym, pozostawiając jak największą swobodę poszukiwaniom twórczym"151. Oceniając jego przemówienie, Putrament zwrócił uwagę, że różnica

${ }^{150}$ C. Budzyńska, Strzępy rodzinnej sagi, Warszawa 1997, s. 407. Biogram Jadwigi Siekierskiej: op. cit.

${ }^{151}$ AAN, KC PZPR, 237/V/225, Stenogram narady na temat węzłowych zadań frontu ideologicznego i kulturalnego, 20, 23 XII 1955 r., k. 9-14, 18-19; ibidem, XIA/138, Tezy robocze do referatu o zjawiskach ideologicznych w środowisku literackim, b.d., k. 9-17. 
tonu w porównaniu do narady w sprawie Poematu była bardzo wymowna, świadczyła o cofaniu się. „Narada się skończyła bez żadnych uchwytnych rezultatów. Potwierdziła ona tylko niezdolność ówczesnego kierownictwa [do] opanowania sytuacji w kulturze" - pisał $^{152}$.

Myślą przewodnią przemówienia Bermana była deklaracja, że partia nigdy nie zrezygnuje z oddziaływania na ideowy kierunek literatury, ale jedyną receptą na przeciwdziałanie fermentowi miała być presja wywierana przez „czołowy” aktyw partyjny na środowisko literackie. Dalszy kierunek miał być wyznaczony w czasie krajowej narady kulturalnej zapowiedzianej przez Bermana na marzec 1956 r., która jednak nie doszła do skutku ze względu na reperkusje XX zjazdu KPZR, śmierć Bieruta i spowodowane przez nie trzęsienie ziemi.

Odnotujmy, że Berman zauważył również pojawienie się „dezorientacji i zachwianej równowagi” w środowiskach dziennikarskich i wśród studentów ${ }^{153}$. Główny mówca mógł liczyć na wsparcie innych, broniących partii przed zamętem. Redaktor naczelny „Trybuny Ludu” Werfel dostrzegał zamęt nie tylko na łamach prasy literackiej, ale już w „Po Prostu” i ostrzegał: „I w tej chwili jest to duże niebezpieczeństwo, że te odpowiedzi, które się przesuwa w prasie - literackiej prasie, trzeba powiedzieć także $\mathrm{w}$ jednym $\mathrm{z}$ młodzieżowych czasopism - to są odpowiedzi, które już idą w masy. I to jest jakaś próba, obiektywnie, towarzysze, apelowania do dołów"154. Bermana wsparli też Kruczkowski i Putrament, który zresztą przedstawił bezkompromisową definicję swobody twórczej w rozumieniu partii: „swoboda twórcza to jest swoboda wyrażania naszej ideologii, ale wcale nie znaczy pełna swoboda wyrażania byle jakiej ideologii. Jesteśmy dyktaturą proletariatu i nie chcemy z tego rezygnować" - mówil, co w gruncie rzeczy okazało się podzwonne dla ówczesnych możliwości partii, ale pozostało jej ambicją do upadku PRL ${ }^{155}$. W porównaniu z naradą na temat poematu Ważyka głosów wspierających Bermana było więcej, ale kilka wypowiedzi, m.in. Wiktora Grosza (również doświadczonego towarzysza) i Kazimierza Brandysa, bardziej liberalnym tonem odbiegało od pozostałych. Przykład Werfla i Putramenta dobrze ilustruje, jak bardzo zmienne/niejednoznaczne mogły być poglądy w tym czasie, a ocena ich postaw krańcowo różna - co każe zachować ostrożność przed wyciąganiem daleko idących wniosków ${ }^{156}$.

152 J. Putrament, Pół wieku. Literaci, Warszawa 1970, s. 314.

153 AAN, KC PZPR, 237/V/225, Stenogram narady na temat węzłowych zadań pionu ideologicznego i kulturalnego..., k. 8.

${ }^{154}$ Cyt. za Z. Rykowski, W. Władyka, op. cit., s. 110.

155 AAN, KC PZPR, 237/V/225, Stenogram narady na temat węzłowych zadań frontu ideologicznego i kulturalnego..., k. 35; ibidem, VII/138, Biuletyn Biura Sekretariatu KC nr 21, 15 I 1956 r., k. 26.

${ }^{156}$ Zob. E. Pasierski, Jerzy Putrament - piewca październików?, w: Październik 1956 w literaturze ifilmie..., s. 139-151. 
Czas pokazał, że była to ostatnia narada tego typu, za pomocą których partia ręcznie sterowała kulturą, i zarazem ostatnia $z$ Bermanem $w$ roli głównego ideologa i nadzorcy „frontu kulturalnego”. Od 1957 r., gdy partia zaczęła odzyskiwać pole, próbowała wpływać na kulturę za pomocą innych, bardziej subtelnych, narzędzi. Komentując przemówienie Bermana, Maria Napiontkowa zwróciła uwagę, że zauważalna dwoistość jego wypowiedzi świadczyła już o wewnętrznym rozchwianiu ideologów, które miało trwałe konsekwencje dla funkcjonowania kultury i sztuki w PRL po 1956 r. Oznaczało milczącą akceptację polityki „rozmaitych obłudnych przyzwoleń: jeśli mały nakład publikacji lub tzw. pismo branżowe to można zamieścić informacje kontrowersyjne, które w wielonakładowych nie mają szans się ukazać, jeśli duże miasto - to może mieć scenę eksperymentalną, ale w mniejszym ośrodku na takie dziwactwa nie ma miejsca, w Dyskusyjnych Klubach Filmowych (DKF) można było oglądać filmy, które nigdy nie weszły do «szerokiej» eksploatacji”"157. Deklaracja Bermana, że władze będą „unikać drobiazgowej ingerencji" i będą posługiwały się inspiracją w odniesieniu do prasy sygnalizowała odchodzenie władz od narzucania i kontrolowania wszystkich treści na łamach gazet i czasopism na rzecz nowego modelu - przyznania prasie przestrzeni swobody w imię podniesienia jej atrakcyjności. Przestrzeń tę, zarówno jeśli chodzi o publikowane treści, jak i odnowienie szaty i form graficznych, gazety szybko wypełniły.

Powyższa teza znajduje potwierdzenie $\mathrm{w}$ decyzjach zapadających $\mathrm{w}$ pierwszej połowie 1956 r. Mimo że środowiska literackie i dziennikarskie w coraz większym stopniu wymykały się spod kontroli, a Polska żyła XX zjazdem KPZR i referatem Chruszczowa, kierownictwo partii akceptowało powstawanie nowych pism literacko-artystycznych (np. „Dialog”), adresowanych do mniejszości narodowych („Nasze Słowo”, „Niwa”) i nowych regionalnych czasopism społeczno-kulturalnych, z których większość okazała się rozsadnikami odwilży także w jej politycznym wymiarze. Czasopisma takie planowano powołać lub zaczęły się ukazywać m.in. w Gdańsku („Kontrasty”), Łodzi („Kronika”), Olsztynie („Warmia i Mazury”), Stalinogrodzie (Katowicach) („Przemiany”), Szczecinie („Ziemia i Morze”), Wrocławiu („Nowe Sygnały”). W uzasadnieniu wniosku o utworzenie dwutygodnika w Stalinogrodzie (Katowicach) czytamy: „Proponuje się, aby pismo nie zawężało zakresu zagadnień, którymi się będzie zajmować, do spraw ruchu artystycznego, zawodowego, literatury i sztuki [...]. Chcemy, aby pismo redagowane w barwnej, ciekawej formie, stało się orężem walki o intelektualny rozwój Śląska i jego wkład do ogólnonarodowej rewolucji kulturalnej”. Na początku lipca, a więc już po buncie Poznania, Sekretariat KC zgodził się na przekształcenie lub powołanie od listopada 1956 r. czasopism w Bydgoszczy („Pomorze”) i Poznaniu

${ }^{157}$ M. Napiontkowa, op. cit., s. 68-69. 
(„Wyboje”) i dopiero wtedy polecił Wydziałowi Kultury przygotowanie oceny pracy nowych redakcji ${ }^{158}$.

W czasie plenarnego posiedzenia zarządu głównego SDP w dniach 24-25 stycznia 1956 r. dyskusje, które do tej pory miały miejsce w czasie spotkań z redaktorami naczelnymi i w gabinetach redakcyjnych, wydostały się na szersze forum; dziennikarze już wyraźnie oczekiwali od SDP zajęcia się sprawami angażującymi uwagę środowiska. Wygłaszający główny referat Arnold Mostowicz wyraźnie jednak chłodził oczekiwania, gdy w ślad za Bermanem mówił o zamęcie ideologicznym w środowiskach literackich i dziennikarskich, choć równocześnie przyznał, że to właśnie na łamach czasopism literackich ukazały się artykuły dotyczące spraw najważniejszych i najtrudniejszych ${ }^{159}$. Skądinąd podobnie mętna była wymowa artykułu Korotyńskiego Uwagi o krytyce w prasie, który ukazał się na łamach styczniowych „Nowych Dróg”160. Wypowiedź reprezentującego kierownictwo partii Morawskiego dziennikarze mogli zinterpretować jako łagodzącą wrażenie po krytyce „Trybuny Ludu” i ataku Bermana - zwłaszcza gdy werbalnie wsparł przyjęty przez zgromadzonych postulat wystosowania do władz partii memoriału $\mathrm{z}$ apelem o zagwarantowanie skuteczności krytyki prasowej.

$\mathrm{Z}$ wielu wypowiedzi przebijało rozczarowanie i rezygnacja $\mathrm{z}$ powodu kolejnych jałowych dyskusji na temat krytyki: mówca z Gdańska zauważył nawet, że podobne do siebie referaty na temat nieskuteczności krytyki słyszał już pięć razy i skoro nie ma perspektyw zmiany stanu rzeczy może lepiej „nie rozwijać takiej krytyki w prasie, bo tylko się kompromituje". Mimo wszystko próbowano bezskutecznie zakreślić granice dopuszczalnej krytyki, apelowano do kierownictwa partii o ich dookreślenie m.in. za pomocą zmian w prawie. W czasie ożywionej dyskusji głośno wybrzmiały słowa przedstawicieli prasy regionalnej, którzy po raz pierwszy tak otwarcie mówili o swojej dyskryminacji na tle sytuacji uprzywilejowanych dziennikarzy z warszawskich redakcji ogólnopolskich - które miały większy prestiż, lepiej płaciły i cieszyły się nieporównanie większą swobodą. Dziennikarze z gazet terenowych mówili o słabości wojewódzkich oddziałów SDP, panującym w nich marazmie, lekceważeniu ze strony Wydziału Prasy KC i innych centralnych

158 AAN, Kancelaria Sejmu, 21, Pismo prezesa RSW „Prasa” do marszałka sejmu PRL, 14 XI 1956 r., k. 468-469; AAN, KC PZPR, V/42, Protokół nr 91 posiedzenia Sekretariatu KC, 7 II 1956 r., k. 250; ibidem, V/42, Protokół nr 97 posiedzenia Sekretariatu KC, 27 III 1956 r., k. 267; ibidem, V/48, Wniosek Wydziału Kultury KC w sprawie powołania nowych czasopism społeczno-kulturalnych, 20 VI 1956 r., k. 56-57; ibidem, Wniosek o utworzenie dwutygodnika społeczno-kulturalnego („Przemiany”), k. 32-34.

${ }^{159}$ W lutym 1956 r. na wniosek Sekretariatu KC CKKP ukarała Mostowicza upomnieniem w związku ze zbyt krytycznymi artykułami na temat Ministerstwa Rolnictwa oraz Pszczółkowskiego na łamach „Gazety Krakowskiej” i „Szpilek”, AAN, KC PZPR, V/42, Protokół nr 93 posiedzenia Sekretariatu KC, 21 II 1956 r., k. 256.

${ }^{160}$ H. Korotyński, Uwagi o krytyce w prasie. Z doświadczeń redaktora gazety, „Nowe Drogi” 1956, nr 1. 
agend partii i państwa. Domagali się od władz stowarzyszenia wsparcia w konfliktach $\mathrm{z}$ bezpardonowo ingerującymi w ich publikacje komitetami wojewódzkimi PZPR. Ich wypowiedzi nie tylko potwierdzają wyraźne uprzywilejowanie prasy literacko-kulturalnej w porównaniu do gazet codziennych, ale są świadectwem wielkiego zróżnicowania ówczesnej prasy na promieniującą odwilżową swobodą prasę centralną i prasę prowincjonalną, do której zaliczano wszystkie redakcje pozawarszawskie ${ }^{161}$. Kolejne posiedzenie prezydium zarządu głównego 27 lutego miało przebieg rutynowy, planowano zebrania sekcji poświęcone tematyce międzynarodowej, rolnej, spotkania z przedstawicielami ministerstw i - bardzo wstępnie - dyskusje na temat młodzieży i moralności ${ }^{162}$.

Co ciekawe podobnie - choć $\mathrm{z}$ innej strony - kwestię sytuacji w centrum i na peryferiach oceniał jeden z wyróżniających się przytomnością uczestników narady tzw. pionu propagandowego w dniach 23-28 stycznia 1956 r. ${ }^{163}$ Sekretarze komitetów wojewódzkich ds. propagandy oraz pracownicy Wydziału Propagandy KC i jego wojewódzkich odpowiedników obradowali niemal równocześnie z dziennikarzami. Na tle morza ideologicznego lania wody trzeźwością wyróżniało się trzech mówców, z których jeden - Ludwik Krasucki ze Szczecina - odnotował właśnie wyraźną dysproporcję między Warszawą, a prowincją, jeśli chodzi o powiew „nowego”. „O ile w aktywie centralnym odbywają się na ogół szerokie dyskusje wokół nowych problemów, to w KW takimi sprawami interesuje się już tylko wąska grupa ludzi, a do $\mathrm{k}$ [omitetów] p[owiatowych] docierają jedynie pewne odgłosy tych dyskusji i to najczęściej przypadkowo. Stąd też dyskusje w aktywie toczą się obok instancji partyjnych na gruncie prywatnym poza głównym nurtem życia partyjnego" - mówił. Z jednej strony odnotowywał, że „stępiło się ostrze krytyki imperializmu, są przejawy czołobitności wobec techniki i kultury Zachodu”, a z drugiej trzeźwo stwierdzał, że „w języku propagandy, szczególnie na dole - wiele tam lakiernictwa, drewnianego języka, nie liczenia się z nastrojami. Często język prelegenta powiatowego jest językiem z przed 5-6 laty"164. Dla lepszego zorientowania terenu w aktualnej „linii” proponował organizowanie w KC systematycznych, co miesiąc, zebrań kierownictw wojewódzkich wydziałów propagandy. Ten głos wyróżniał się na tle innych, co jednak nie dziwi - Krasucki nie był typowym aparatczykiem, ale dziennikarzem związanym $\mathrm{z}$ „Trybuną Ludu" i w szczecińskich kręgach partyjnych miał opinię liberała ${ }^{165}$. Zwróćmy

\footnotetext{
${ }^{161}$ M. Przeperski, Władze i dziennikarze..., s. 100-105.

162 AAN, KC PZPR, 237/VIII/364, Biuletyn nr 23 Wydziału Prasy KC, 8 III 1956 r., k. 29.

163 AAN, KC PZPR, 237/VIII/238-239, Stenogram krajowej konferencji pracowników aparatu propagandowego, 23-29 I 1956.

164 AAN, KC PZPR, V/48, Informacja o naradzie sekretarzy propagandy KW, b.d., k. 160-161.

${ }^{165}$ Ludwik Krasucki (1925-2004) - działacz partyjny i społeczny, dziennikarz i scenarzysta. Członek Czerwonego Harcerstwa (1936-1939), żołnierz Armii Krajowej, więzień obozu koncentracyjnego w Stutthofie, zaangażowany w obozowy ruch oporu. Po wojnie członek PPS, m.in.
} 
uwagę na jego głos, dobrze charakteryzujący sytuację w ośrodku peryferyjnym, głęboko zanurzonym w - zdawałoby się - mijającej już epoce, do którego odwilż docierała $z$ trudem ${ }^{166}$. Równie krytyczny referent $\mathrm{z}$ województwa krakowskiego mówił o bezmyślności propagandy, zaniechaniu badania jej skuteczności i niedostatecznym rozeznaniu nastrojów poszczególnych środowisk. Sygnalizował, że w Krakowie w środowiskach inteligenckich i wśród młodzieży studenckiej „wroga propaganda zmierza do podważania marksizmu leninizmu”. Poczucie zagubienia dominujące wśród ludzi odpowiedzialnych za przekaz propagandowy najlepiej jednak oddawały słowa Wincentego Kraśki, ówczesnego sekretarza KW z Poznania: „po [III] plenum wiemy czego nie należy robić, nie wiemy natomiast jak należy pracować po nowemu"167.

$\mathrm{Na}$ koniec narady zabrał głos Morawski. Kilka dni wcześniej, 24 stycznia, przemawiał w czasie posiedzenia plenarnego zarządu SDP, gdzie wsparł pomysł dziennikarzy wystosowania memoriału do władz w sprawie braku skuteczności krytyki prasowej i - niezbyt przekonująco - bronił uchwały Biura Politycznego w sprawie „Trybuny Ludu”168. Teraz musiał zmierzyć się z poczuciem frustracji terenowych przedstawicieli aparatu propagandowego. Był skazany na porażkę - przyznając rację wielu mówcom, nie miał dla nich prostych odpowiedzi. Jak można podejrzewać, słuchali go z rosnącym zdumieniem. Byłoby eufemizmem stwierdzić, że odpowiedzialny za propagandę sekretarz KC po prostu inaczej rozłożył akcenty. Mówił zupełnie innym językiem niż miesiąc wcześniej drugi po Bierucie, nadzorujący „front ideologiczny” towarzysz „Jakub”. Wielu zapewne zadawało sobie pytanie o to, jaka jest teraz obowiązująca linia partii. Rozdźwięk w elicie przywódczej PZPR, który do tej pory wpływał na niespójność pisemnych instrukcji i wytycznych, teraz znalazł wyraźne odzwierciedlenie w wystąpieniach na forum wewnętrznym, co oznaczało kolejne złamanie żelaznej zasady jedności.

Sekretarz KC posługiwał się figurą wroga charakterystyczną dla stalinowskiego języka, ale bagatelizował jego znaczenie. „Byłoby dużym błędem, gdybyśmy

członek Rady Naczelnej i redaktor „Przeglądu Socjalistycznego”. Od 1948 r. w PZPR. Redaktor prasy terenowej PZPR (1948-1955), sekretarz ds. propagandy KW PZPR w Szczecinie (19541956). Dziennikarz „Trybuny Ludu” (1954-1974), w latach siedemdziesiątych i osiemdziesiątych związany z „Nowymi Drogami”, „Polityką" i „Życiem Warszawy”. Autor kilku książek propagandowych, scenariuszy filmowych. Członek wielu stowarzyszeń i fundacji, m.in. SDP, Stowarzyszenia Żydów Kombatantów i Poszkodowanych w II Wojnie Światowej oraz Fundacji „Polsko-Niemieckie Pojednanie”. W świetle materiałów Służby Bezpieczeństwa od 1985 r. zarejestrowany jako tajny współpracownik wykorzystywany do inwigilacji przebywających w Polsce obcokrajowców. Biogram za: E. Krasucki, „W świetle uchwał XX Zjazdu...”. Szczecińskie echa moskiewskich wydarzeń z lutego 1956 roku, cz. 2, „Zapiski Historyczne” 2013, nr 1, s. 55.

${ }^{166}$ E. Krasucki, „W świetle uchwał XX Zjazdu...”. Szczecińskie echa moskiewskich wydarzeń z lutego 1956 roku, cz. 1, „Zapiski Historyczne” 2012, nr 4, s. 141-144, 156.

167 AAN, KC PZPR, V/48, Informacja o naradzie sekretarzy propagandy KW, b.d., k. 162.

${ }^{168}$ M. Przeperski, Władze i dziennikarze..., s. 101-102. 
z uwagi na to, że wróg to wykorzystuje, chcieli tonować czy ograniczać rozwój naszej krytyki - mówił - i byłoby grubym błędem, gdybyśmy różne niesłuszne poglądy czy sporne sprawy, które się rozwijają w dyskusjach, jakie się toczą zwłaszcza w środowiskach naukowo-kulturalnych, chcieli kwalifikować jako poglądy wrogie" ${ }^{169}$. W rosnącej aktywności i dyskusjach w środowiskach twórczych widział nie tyle „zamęt ideologiczny”, ile ożywczy, „twórczy ferment”. Dostrzegał błędy po stronie partii, przyznając wprost, że nie ma ona w świecie kultury wielkich wpływów i poddawał w wątpliwość, czy przy takim stosunku do twórców można organizować i prowadzić czasopismo kulturalno-artystyczne. Krytycznie oceniał praktyki drobiazgowego ingerowania w treść publikowanych tekstów. „Raczej coś w rodzaju urzędu cenzorskiego, aniżeli kierownictwem politycznym stają się nasze ogniwa" - oceniał, przy okazji wyrażając (raczej naiwną) wiarę, że dzięki odpowiedniej dyskusji i inspiracji partia nie będzie musiała ingerować w poszczególne teksty, gdyż „sami twórcy będą tych rzeczy pilnowali”. Nie niepokoiła go rosnąca aktywność społeczeństwa, wręcz przeciwnie, zdawało się, że dostrzega jego podmiotowość, choć drastycznie mylił się w optymistycznej ocenie stosunku społeczeństwa do władzy komunistycznej, „bo przecież również wśród robotników i chłopów poruszane są różne tematy polityczne, ekonomiczne, moralne. [...] Czy to wróg eskaluje dyskusję na te problemy? Ktoś się tak wyraził, trudno się z tym pogodzić. To są rzeczywiście dla wszystkich ludzi najbardziej żywotne problemy. Jakiż w końcu jest główny sprawdzian wartości ustroju, jeśli nie co on ludziom daje, jak ludzie w nim żyją. I ludzie pytają: mija 11 lat a socjalizmu jeszcze nie ma. Dobrobytu jeszcze nie ma, żyje się ciężko, jak ma być dalej?”170.

Morawski bardzo krytycznie oceniał stan realizacji postanowień III plenum KC, mającego przynieść partii odnowę, które według niego - zwłaszcza na szczeblu wojewódzkim i w terenie - niewiele zmieniło. Mówił o zauważalnym zniechęceniu dziennikarzy i osłabieniu krytyki prasowej spowodowanym przez uchwałe Biura Politycznego w sprawie „Trybuny Ludu”, którą - według niego - „W sposób niesłuszny i fałszywy" zrozumiano w redakcjach i organizacjach partyjnych. „Z uchwały, która krytykowała błędy i wypaczenia w krytyce wyciągnięto wniosek - widocznie w ogóle lepiej ciszej z krytyką" - mówi1 ${ }^{171}$. Po raz pierwszy członek kierownictwa partii nadał krytyce prasowej tak duże znaczenie, mówiąc, że to jest „bezpośrednia pomoc dla partii w ujawnianiu i zwalczaniu różnych złych objawów”. „Wtedy ta krytyka będzie się prawidłowiej i żywiej rozwijać, a to będzie miało nie mały skutek na rozwój ustnej krytyki na zebraniach partyjnych i na zebraniach ludności" - tym samym niemal wprost przyznawał, że celem jest odwołanie się do społeczeństwa i wywarcie presji na instytucje aparatu władzy, co

169 AAN, KC PZPR, 237/VIII/239, Stenogram krajowej konferencji pracowników aparatu propagandowego, 29 I 1956 r., k. 296.

170 Ibidem, k. 284, 304.

${ }^{171}$ Ibidem, k. 293. 
musiało zrobić na słuchaczach piorunujące wrażenie. Morawski apelował do nich, by wspierali redakcje w „rozwijaniu krytyki” i wyszedł naprzeciw oczekiwaniom dziennikarzy, gdy zapowiedział znacznie ostrzejszą walkę przeciwko „dławicielom krytyki" (na słowach się skończyło). Więcej, lokalnym aparatczykom od propagandy stawiał dziennikarzy jako wzór do naśladowania: powiatowi prelegenci i agitatorzy właśnie z gazet mieli teraz czerpać argumenty, a nie oczekiwać na "gotową papkę propagandową" z centrali ${ }^{172}$. Jakimi wrażeniami podzielili się po powrocie do swoich komitetów wojewódzkich słuchający Morawskiego działacze $\mathrm{z}$ terenu? Centrum wyraźnie wspierało prasę, co z perspektywy lokalnych struktur władzy potęgowało niepokój i niepewność o przyszłość.

*

Analiza polityki PZPR wobec prasy w okresie między III plenarnym posiedzeniem KC a XX zjazdem KPZR nie powinna ograniczać się do proponowanego przez Morawskiego wyjaśnienia - polityki „zygzakowatej linii” względnie „walki na dwa fronty”. Była ona owocem niejednolitego podejścia najważniejszych instancji kierowniczych partii, Biura Politycznego i Sekretariatu KC spowodowanego przez postępującą erozję spójności ideologicznej i żelaznej dyscypliny, podmywającej niekwestionowaną dotychczas pozycję ścisłego centrum władzy: Bieruta, Bermana i Minca. Politbiuro naciskało hamulec. Po raz pierwszy w kwietniu 1955 r., gdy w przyjętej uchwale - liście do komitetów wojewódzkich i powiatowych - de facto reinterpretowało postanowienia "odwilżowego" III plenum KC. Po raz drugi, gdy pod koniec roku przyjęło uchwałę w sprawie „Trybuny Ludu”, oceniło krytycznie „Nowe Drogi” i podjęło zakończoną fiaskiem próbę uruchomienia ofensywy ideologicznej. W przypadku wspomnianego listu największy wpływ na treść miał Berman, ale zapewne musiał uwzględnić stanowiska pozostałych członków komisji: Morawskiego, Zambrowskiego i Titkowa. Władze karały tylko odpowiedzialnych za zbyt odważne publikacje i ani jednego odpowiedzialnego za publikacje - używając języka epoki - „lakiernicze”. Jeśli jednak prześledzimy wypowiedzi nadzorującego propagandę Morawskiego zauważymy, że często podkreślał znaczenie rozwoju „krytyki prasowej” i wspierał prasę $\mathrm{w}$ roli krytycznego obserwatora. Morawski reprezentował tych ludzi z elity PZPR, którzy opowiadali się za ostrożnymi zmianami i zapewne postrzegali śmielszą krytykę patologii gospodarczych i społecznych jako potrzebny wentyl bezpieczeństwa. W styczniu 1956 r. sekretarz KC wyraźnie dystansował się od niedawnych uchwał Politbiura w sprawie „Trybuny Ludu” i prezentował jako sprzyjający postulatom środowiska dziennikarskiego zwolennik liberalizacji. Niejednoznaczne sygnały powodowały z jednej strony ferment i narastającą frustrację środowiska dziennikarskiego, a z drugiej strony głębokie zaniepokojenie i opór

172 Ibidem, k. 294, 306. 
centralnych i terenowych struktur stalinowskiego aparatu władzy. Wszystkie te elementy składały się na niestabilną mieszankę, która do wybuchu potrzebowała tylko impulsu. Ten przyszedł z Moskwy, gdzie rozpoczynał się XX zjazd KPZR.

\section{History of a two-front fight. The authorities - the press - journalists 1953-55/56 (Abstract)}

The main purpose of the article is to analyse the press policy conducted by the communist party and the relationship between the authorities and journalists in 1953-55/56 against the background of political and cultural changes in Poland. The analysis is based on the broad research in archives and press releases as well as literature on the subject; the subject is presented both from the national and local perspective. In the first phase of changes after Stalin's death the press policy of the Polish United Workers' Party (PUWP) was a result of more pragmatic line set by the Soviet Union in the communist block after 1953. When, at the end of 1954, the Thaw in Poland found its own dynamic, a growing discrepancy in the Party's elite and incoherent policy contributed to the expanding margin of freedom of journalists, especially in the capital city of Warsaw. The press policy of the PUWP was the fruit of difference of opinion between the Party's leaders, the Political Bureau, and the Secretariat of the Central Committee. The Political Bureau was slamming the brakes. For the first time in April 1955, when in a letter to the central committees of voivodeships and districts they in fact reinterpreted the decisions of the post-Thaw Third Plenum of the Central Committee. For the second time, when at the end of 1955 they criticised the Trybuna Ludu (People's Tribune) daily and Nowe Drogi (New Ways) monthly, and undertook a failed attempt to launch an ideological offensive. Jerzy Morawski, who was put in charge on behalf of the Central Committee Secretariat, represented this part of the Party's elite who supported cautious changes and encouraged the press to criticize economic and social pathologies, regarding it as a necessary safety valve. An analysis of Morawski's statements reveals that, in general, he supported the press in a role of critical observer. In January 1956 the Central Committee secretary explicitly distances himself from recent decisions of the Political Bureau on the Trybuna $L u d u$ and presented himself as the advocate of liberalisation. Ambiguous signals from the centre of power fomented unrest and frustration of the journalist circles in Warsaw, who at the turn of 1956 in their large part rebelled against the model of press seen as a tool of party propaganda. On the other hand, however, signals sent from the centre exerted pressure and were resented by the central and local structures of the Stalinist party-state apparatus. Under these unstable circumstances the explosion was triggered by Moscow, where the 20th Congress of the Communist Party of the Soviet Union was beginning.

\section{Bibliografia}

\section{Archiwalia}

Archiwum Akt Nowych

Kancelaria Sejmu 21

Komitet Centralny PZPR

Plena KC III/12

Biuro Polityczne V/27, V/30, V/31, V/36, V/38, V/42, V/48

Sekretariat 237/V/30, 237/V/213, 237/V/225

Sekretariat Bolesława Bieruta XIA/138

Sekretariat KC VII/12, VII/13, VII/138

Biuro Prasy 237/XIX/10, 237/XIX/68 
Biuro Listów i Inspekcji 237/XXV/13

Wydział Nauki 237/XVI/207

Wydział Propagandy KC 237/VIII/214, 237/VIII/238, 237/VIII/239, 237/VIII/361, 237/ VIII/362, 237/VIII/363, 237/VIII/364

Centralna Kartoteka CK XX/18699, Akta osobowe Henryka Korotyńskiego, CK XX/2004, Akta osobowe Jerzego Morawskiego, CK XX/4901, Akta osobowe Mariana Mikołajczyka, CK XX/3154, Akta osobowe Leona Przemskiego, AAN, KCPZPR, CKXX/4832, Akta osobowe Leszka Krzemienia

\section{Prasa}

„Nauka Polska” (1953-1956)

„Nowa Kultura” (1953-1956)

„Nowe Drogi” (1953-1956)

„Po prostu” (1954-1956)

„Prasa Polska” (1953-1956)

„Przegląd Kulturalny” (1953-1956)

„Sztandar Młodych” (1953-1956)

„Trybuna Ludu” (1953-1956)

Jedlicki W., Chamy i Żydy, „Kultura” (Paryż) 1962, nr 12

Październik 1956 [dyskusja nad artykułem Witolda Jedlickiego Chamy i Żydy], Instytut Badania Zagadnień Krajowych, Londyn 1963

\section{Źródła wydane i opracowania}

Békés C., Europa Środkowo-Wschodnia, 1953-1956, w: Historia zimnej wojny, t. 1: Geneza, red. M.P. Leffler, O.A. Westad, Oświęcim 2017

Biogram Jadwigi Siekierskiej, w: Internetowy Polski Słownik Biograficzny, http://www.ipsb.nina. gov.pl/a/biografia/jadwiga-siekierska

Budzyńska C., Strzępy rodzinnej sagi, Warszawa 1997

Ceranka P., Historia pewnego artykułu, „Pamięć i Sprawiedliwość” 2006, nr 2(10)

Chrząstek T., Na kulturalnym froncie. Analiza zawartości tygodnika „Nowa Kultura” 1950-1963, Warszawa 2016

Ciborska E., Leksykon polskiego dziennikarstwa, Warszawa 2000

Ciborska E., Polska Agencja Prasowa. Tradycja i współczesność, „Rocznik Historii Prasy Polskiej” 1998, nr 1-2

Czeczott J., Petersburg. Miasto snu, Wołowiec 2017

Detka J., W cieniu Poematu dla dorostych. O poematach rozrachunkowych czasu odwilży, w: Październik 1956 w literaturze i filmie, red. M. Zawodniak, P. Zwierzchowski, Bydgoszcz 2010

Erenburg I., Odwilz, tłum. J. Brzechwa, Warszawa 1955

Fik M., Kultura polska po Jatcie. Kronika lat 1944-1981, Londyn 1989

Friszke A., Wiktor Woroszylski. Polityka i literatura, w: W. Woroszylski, Dzienniki, t. 1: 1953-1982, red. A. Dębska, oprac. przypisów K. Rokicki, B. Kaliski, A. Dębska, Warszawa 2017

Gawin D., Wielki zwrot. Ewolucja lewicy i odrodzenie idei społeczeństwa obywatelskiego 1956-1976, Kraków 2013

Giedroyc J., Autobiografia na cztery ręce, oprac. K. Pomian, Warszawa 1994

Grygo E., Prasa partyjna wobec wydarzeń w 1956 roku, „Kwartalnik Historii Prasy Polskiej” 1985, nr 1 Grygo E., Z problematyki kierownictwa prasa PZPR w latach 1948-1959, „Kwartalnik Historii Prasy Polskiej" 1984, nr 1

Janowski W., Kochański A., Informator o strukturze i obsadzie personalnej centralnego aparatu PZPR 1948-1990, red. K. Persak, Warszawa 2000 
Karpiński J., Porcja wolności (Październik 1956), w: idem, Wykres gorączki. Polska pod rządami komunistycznymi, Lublin 2001

Korotyński H., Trzy czwarte prawdy. Wspomnienia, Warszawa 1987

Kozieł A., Między rewizjonizmem a dogmatyzmem. Prasa polska w 1957 roku, w: Materiały pomocnicze do historii dziennikarstwa Polski Ludowej, red. A. Słomkowska, Warszawa 1988

Kozieł A., Polityka prasowa w 1956 roku, w: Październik 1956 roku. Początek erozji systemu, red. M. Jabłonowski, S. Stępka, Pułtusk 2007

Kozieł A., Studium o polityce prasowej PZPR w latach 1948-1957, Warszawa 1991

Kramer M., The early post-Stalin succession struggle and upheavals in East-Central Europe. Internal-external linkages in Soviet policy making, „Journal of Cold War Studies” 1, 1999, nr 1

Krasucki E., „W świetle uchwał XX Zjazdu...”. Szczecińskie echa moskiewskich wydarzeń z lutego 1956 roku, cz. 1, „Zapiski Historyczne” 2012, nr 4; cz. 2, „Zapiski Historyczne” 2013, nr 1

Krzemień L., Kropla w potoku, Warszawa 1963

Kutkowski A., Polityka karna władz PRL w 1953 r. - jej wyznaczniki i konsekwencje, w: Yesterday. Studia $z$ historii najnowszej. Księga dedykowana prof. Jerzemu Eislerowi w 65. rocznicę urodzin, red. J. Olaszek, A. Dudek, Ł. Kamiński, K. Kosiński, M. Przeperski, K. Rokicki, P. Sasanka, R. Spałek, S. Stępień, Warszawa 2017

Lipiński P., Bierut. Kiedy partia była bogiem, Wołowiec 2017

Łopieńska B.N., Szymańska E., Stare numery, Londyn 1986

Michnik A., „O roku ów!” (kilka przypuszczeń na temat Polskiego Października), w: 1956 (nieco) inne spojrzenie, red. J. Kochanowski, J. von Puttkamer, Warszawa 2016

Mielczarek T., Kultura i polityka. Kultura, życie umysłowe, media 1944-1989, Warszawa 2010

Mielczarek T., Liberałowie i rewizjoniści. Z dziejów „Przeglądu Kulturalnego” (1952-1963), „Kieleckie Studia Bibliologiczne" 2000, nr 5

Mielczarek T., Od „Nowej Kultury” do „Polityki”. Tygodniki społeczno-kulturalne i społeczno-polityczne PRL, Kielce 2003

Mikołajczyk M., Rewizjoniści. Obecność w dyskursach okresu PRL, Kraków 2013

Modzelewski - Werblan. Polska Ludowa. Rozmawia Robert Walenciak, Warszawa 2017

Napiontkowa M., Teatr polskiego Października, Warszawa 2012

Pasierski E., Jerzy Putrament - piewca październików?, w: Październik 1956 w literaturze i filmie, red. M. Zawodniak, P. Zwierzchowski, Bydgoszcz 2010

Październik 1956 roku. Początek erozji systemu, red. M. Jabłonowski, S. Stępka, Pułtusk 2007

Pietrzak J., Działalność komunistów wśród polskiego wychodźstwa na Bliskim Wschodzie w świetle materiałów kontrwywiadu Polskich Sił Zbrojnych (1944 r.), „Dzieje Najnowsze” 2006, nr 3

Pietrzak J., Sytuacja polityczna w Polsce w latach 1944-1947 w świetle „Biuletynu Wolnej Polski” pisma Związku Patriotów Polskich na środkowych Wschodzie, „Przegląd Nauk Historycznych” 2008, $\mathrm{nr} 1$

Przeperski M., Komisja Prasowa KC PZPR 1956-1957, „Polska 1944/45-1989. Studia i Materiały” 14,2016

Przeperski M., Odwrót od Października. Pacyfikacja prasy i dziennikarzy w latach 1956-1958, „Pamięć i Sprawiedliwość” 2016, nr 2(28)

Przeperski M., Władze i dziennikarze. Stowarzyszenie Dziennikarzy Polskich w 1956 roku, „Pamięć i Sprawiedliwość" 2014, $\mathrm{nr} 2(24)$

Putrament J., Pół wieku. Literaci, Warszawa 1970

Rafalska D., „Po Prostu” i jego rola w 1956 roku, w: Październik 1956 roku. Początek erozji systemu, red. M. Jabłonowski, S. Stępka, Pułtusk 2007

Rafalska D., Między marzeniami a rzeczywistością. Tygodnik „Po Prostu” wobec głównych problemów społecznych i politycznych Polski w latach 1955-1957, Warszawa 2008 
Relacja Ireny Tarłowskiej, 8 I 1988 r., w: Materiały pomocnicze do historii dziennikarstwa Polski Ludowej, t. 17, red. A. Słomkowska przy współpracy D. Mikołajczyk-Grzelewskiej, Warszawa 1992

Relacja ze spotkania z Eligiuszem Lasotą w Instytucie Dziennikarstwa UW, 21 III 1986 r., w: Materiały pomocnicze do historii dziennikarstwa Polski Ludowej, t. 14, red. A. Słomkowska przy współpracy D. Mikołajczyk-Grzelewskiej, Warszawa 1991

Rokicki K., Literaci. Relacje między literatami a władzami PRL w latach 1956-1970, Warszawa 2011

Rykowski Z., Władyka W., Polska próba - Październik '56, Kraków 1989

Sasanka P., Władza - prasa - dziennikarze między XX zjazdem KPZR a Październikiem 1956 r., w: Nie tylko „Po Prostu”. Prasa w PRL dobie „odwilizy” 1955-1958 [w druku]

Smulski J., Immanentne zło komunizmu jako temat literatury i publicystyki „odwilżowej”, w: Październik '56. Odwilż i przełom w życiu literackim i kulturalnym Polski. Materiały ogólnopolskiej sesji naukowej, Rzeszów, 23-25 września 1996 r., red. A. Kulawik, Kraków 1996

Spałek R., U źródeł partii. Z dziejów konfliktów personalno-ideowych $w$ kierownictwie PPR, w: Elity komunistyczne w Polsce, red. M. Szumiło, M. Żukowski, Warszawa-Lublin 2015

Stola D., Kraj bez wyjścia. Migracje z Polski 1949-1989, Warszawa 2010

Szpak E., „Chory człowiek jest wtedy jak coś go boli”. Społeczno-kulturowa historia zdrowia i choroby na wsi polskiej po 1945 r., Warszawa 2016

Szumiło M., Działalność redakcji „Trybuny Ludu” w 1955 roku w świetle raportu ambasadora sowieckiego $w$ Warszawie, „Res Historica” 2013, nr 36

Szumiło M., Roman Zambrowski 1909-1977. Studium z dziejów elity komunistycznej w Polsce, Warszawa 2014

Szumiło M., Wspomnienia Romana Zambrowskiego z Międzynarodowej Szkoły Leninowskiej w Moskwie (1929-1931), „Komunizm. System - ludzie - dokumentacja” 2012, nr 1

Thom F., Beria. Oprawca bez skazy, Warszawa 2016

Torańska T., Aneks, Warszawa 2015

Werblan A., Stalinizm w Polsce, Warszawa 2009, s. 58

Władyka W., Lata 1956-1960, w: Czasopisma społeczno-kulturalne w okresie PRL, red. U. Jakubowska, Warszawa 2011

Władyka W., Na czołówce. Prasa w październiku 1956 roku, Warszawa-Łódź 1989

Pawel Sasanka (ur. 1976) - historyk i wystawiennik, doktor nauk humanistycznych, pracownik Biura Badan Historycznych IPN. Zainteresowania koncentrują się wokół historii Polski po 1945 r., w szczególności politycznej i społecznej historii kryzysów PRL, fotografii jako źródła historycznego i wystawiennictwa. Autor lub współautor wystaw, m.in. „1956. Polska - Węgry. Historia i Pamięć” (2016) oraz „Zimna wojna. Krótka historia podzielonego świata” (2010). Autor m.in. Czerwiec 1976. Geneza, przebieg, konsekwencje (Warszawa 2006), współautor The Cold War. A Short History of a World Divided (Warsaw 2015); Fotografie bez cenzury 1976-1989. Nieoficjalny portret PRL (Warszawa 2014); Zimna wojna. Krótka historia podzielonego świata (Warszawa 2012).

Kontakt: pawel.sasanka@gmail.com 